\title{
Risk-Based Capital Requirements for Banks and International Trade
}

\author{
Banu Demir \\ Bilkent University \\ Tomasz K. Michalski \\ HEC Paris \\ Evren Ors \\ HEC Paris
}

\begin{abstract}
We test the trade finance channel of exports by controlling for the bank credit channel. Using Turkey's July 2012 adoption of Basel II as a quasi-natural experiment, we examine whether shocks to trade financing costs affect exports. With data for 16,662 Turkish exporters shipping 2,888 different products to 158 countries, we find that the share of letters-of-credit-based exports decreases (increases) when the associated risk weights for counterparty exposure increase (decrease) after the adoption of Basel II. However, growth of firm-product-country-level exports remains unaffected. Trade financing might have a lesser role in exports than previously suggested by the previous literature. (JEL G21, G28, F14)
\end{abstract}

Received October 26, 2014; editorial decision March 15, 2017 by Editor Philip Strahan.

A growing body of empirical research shows that shocks to a country's banks affect international trade. For example, Amiti and Weinstein 2011) show that shocks to the financial health of Japanese banks led to a drop in the number of exports from Japanese firms for which these institutions acted as a main bank, holding everything else constant (see also Chor and Manova 2012;

\footnotetext{
We thank Philip Strahan (the editor) and two anonymous referees for their invaluable suggestions. We also thank Marc Auboin, Mark Carey, Olivier De Jonghe, Jérôme Héricourt, David Martinez Miera, George Pennacchi, and Veronica Rappoport for their valuable discussions, as well as audiences at the 2013 European Trade Study Group Annual Conference, 2014 Bank Structure and Competition Conference of the Federal Reserve Bank of Chicago, 2014 FDIC/JFSR Bank Research Conference, 2014 Royal Economic Society's Annual Conference, 2015 American Economic Association Annual Conference, 2016 AEFIN Finance Forum, 2016 European Finance Association Annual Conference, as well as seminar participants at Aalto University, Audencia, Banque de France-Authorité de Contrôle Prudentielle, Bilkent University, European Central Bank, HEC Paris, the IMF, Paris-Dauphine University, WHU School of Management, and Geneva Financial Research Institute for their helpful comments. All remaining errors are our own. Michalski and Ors have benefitted from French National Research Agency (ANR) funding for this project [grant number ANR-11- IDEX-0003/Labex Ecodec/ANR-11LABX-0047]. Demir thanks the International Economics Section at Princeton University for their hospitality. Supplementary can be found on The Review of Financial Studies web site. Send correspondence to Evren Ors, Department of Finance, HEC Paris, 78351 Jouy-en-Josas, France; telephone: +33.1.39.67.71.23. E-mail: ors@hec.fr.
}

(c) The Author 2017. Published by Oxford University Press on behalf of The Society for Financial Studies. All rights reserved. For Permissions, please e-mail: journals.permissions@ oup.com. doi:10.1093/rfs/hhx062

Advance Access publication July 27, 2017 
Del Prete and Federico 2014). This body of evidence is consistent with both an international trade finance channel and a more general bank credit channel. A number of papers focus on the bank credit channel, while controlling for the international trade finance channel. For example, Paravisini et al. 2015) show that the intensive margin of exports drops for Peruvian firms whose local banks were negatively affected by an international funding shock. We contribute to this line of research by directly examining the importance of the international trade finance channel for exports. To the best of our knowledge, our paper is the first to directly identify the trade finance channel of exports, while controlling for the bank credit channel.

Our identification relies on a shock that specifically affects the cost of a commonly used international trade financing instrument. Our setting allows us to compare how exports that relied on this financing instrument ex ante change after the shock with exports that did not. Moreover, our setup allows us to control for other possible explanations of changes in exports over the same period. Importantly, we are able to control for the effects of a bank credit channel. We find that, controlling for other factors, the share of firm-country-product-level exports relying on the international trade finance instrument that we consider is negatively related to the changes in its cost. Interestingly, we find that the same shock has no effect on the growth of total exports at the firm-country-product level. As such, our results call into question the relative importance of shocks to trade-specific finance for international trade and suggest, instead, that a more general bank credit channel might drive the results observed in the previous papers.

More specifically, we examine the impact of the adoption of Basel II on the letters-of-credit-financed exports for a particular country 1 Letters of credit are standard international trade financing instruments issued by an importer's bank 2 The importing firm would then send the instrument to the exporter. The latter would present the received letter of credit to its local bank, together with documents needed as proof of export transaction, for payment. Banks that issue and receive letters of credit have to hold the instrument as an off-balance sheet item, and doing so creates a capital charge for both institutions 3 For the bank that holds the letter of credit, the related capital requirement is calculated by multiplying the nominal value of the instrument by a credit conversion factor

1 These are commercial letters of credit, rather than the standby letters of credit typically used for credit enhancement.

2 Other main methods of payment in international trade are "cash in advance" (in which the importer bears the transaction risk by paying the exporter prior to shipment) and "open account" (in which the exporter bears the transaction risk by getting paid by the importer after the reception of goods).

3 In some countries, for example, the United States, the confirmed letters of credit can be sold in the money market as bankers' acceptances. In Turkey, however, there is no such secondary market: Once confirmed, letters of credit have to be held as off-balance items until maturity. 
to obtain the on-balance sheet equivalent and then with a risk weight to adjust for the issuing bank's counterparty-risk exposure 4

In this paper, we focus on a country with a particular form of Basel II adoption that allows us to isolate the impact of the changes in the cost of holding letters of credit on exports. Turkey's banking regulators required that all banks operating in the country move from Basel I to the standardized approach of Basel II as of July 1, 2012. Under Basel II, for the Turkish exporters' banks the risk weights, and hence the cost of holding letters of credit, depend on the agency rating of the counterparty bank that issues the letter of credit for the importer. In contrast, under Basel I, the risk weights were based on whether the counterparty bank was located in a member country of the Organisation for Economic Co-operation and Development (OECD) or not (i.e., without regard to counterparty risk) with a preferential treatment for OECD-based counterparties. This intersection of Basel I and II rules results in two sets of identification schemes. The resultant changes in the risk weights are expected to impact exports to OECD versus non-OECD countries differently (more details are provided in Section 1.2).

In testing for the international trade finance channel, our hypothesis is that increases (decreases) in the costs of holding letters of credit associated with international trade, due to higher (lower) risk weights after the adoption of Basel II, will lead to a decrease (increase) in exports, all else being equal. To test this conjecture, we use difference-in-differences models, estimated using ordinary least-squares (OLS) regressions, where the dependent variable is the letters-of-credit-based share of exports at the firm-country-product level. Relying on the share of letters-of-credit-based exports allows us to implicitly control for demand effects. We take the first-difference of the share of exports in order to account for the observed differences in pre-Basel-II time trends across the treatment groups (for which the risk weights change) and the control groups (for which the risk weights remain the same). This triple-differences approach allows us to control for confounding factors at the firm-countryproduct level so long as they remain constant over two consecutive annual periods (see, e.g., Khandelwal, Schott, and Wei 2013). We also note that for any unaccounted variation that could influence our findings, the remaining confounding factors' impact would need to be systematic in order to generate the same effects (with the opposite signs) in two separate samples: OECD and non-OECD. This is an economically implausible scenario given that our firmcountry-product triplets cover 16,662 exporters, 158 destinations, and 2,888 six-digit Harmonized System (HS6) product categories.

Our findings support the hypothesis described above. For the OECD sample, our baseline regressions indicate that the share of letters-of-credit-based exports decrease by $11.80 \%$ given the increase in the affected risk-weight category. This result implies a risk-weight elasticity of letters-of-credit-based share of exports

\footnotetext{
4 For the letter of credit issuing bank, the related counterparty is the importing firm that requested the instrument.
} 
of -0.0787 at the firm-country-product level. We find somewhat smaller, yet comparable, results for the non-OECD sample: The decrease in risk weights generates a 5.96\% increase in export share for the affected rating categories. These results are robust to changes in the empirical specifications through additional fixed effects or control variables, different standard errors clustering, or limiting the sample to specific product categories to better control for credit conversion factors. A placebo (falsification) test with a fictitious Basel II adoption date of July 1, 2011, suggests that our results are not due to the anticipation of the new capital regulation's implementation.

However, the findings on export shares do not directly answer the question of whether Basel II adoption negatively affected trade flows as has been suggested in the financial press and in banking surveys. To test for this possibility, we run separate export growth regressions. We find no discernable effect: Even though firm-country-product-level total exports aggregated over all payment types appear to respond negatively (positively) to the associated risk weight increases (decreases), the observed effects are not statistically significant. Overall, our findings imply that the international trade financing channel (as measured by letters of credit used in international trade) might have a lesser role in exports than previously envisioned.

\section{Identification, Empirical Specifications, and Data}

In this section, we detail our identification strategy, empirical specifications, and data. Our evidence comes from Turkey, a member of the OECD, the World Trade Organization (WTO), and the Group of Twenty (G-20). Turkey overwhelmingly exports manufactured goods, making it a large, diversified economy that is relevant for studying global trade.

As of 2012, the country had the world's 17th largest economy, was the 22nd largest exporter by value (15th largest exporter in manufactured goods that we examine), and was the 14th largest importer 5 Turkey has been in a customs union for manufactured goods with the European Union (EU) since 1996 and is the fifth largest exporter to this economic zone (sixth largest in manufactured goods) and its seventh largest importer 6 Moreover, the manufactured goods that we examine formed approximately $94 \%$ of the total amount of Turkish goods exported in 2012.

\subsection{Identification strategy}

The way in which Basel II was implemented in Turkey, when combined with the availability of detailed exports data, provides us with a particularly

5 Economy size rankings are based on the 2012 estimates of the International Monetary Fund (IMF). Trade related rankings are based on the 2011 estimates of the WTO. These rankings treat the EU as a single economy consisting of 27 member-country economies.

6 The EU-Turkish customs union does not cover agriculture or the services sector. This said, manufactured goods include processed food items. 
suitable quasi-natural experiment for examining the international trade finance channel. Turkish banking regulators required that Basel II be implemented in its standardized approach by July 1, 2012 7 One consequence is that we do not have to worry about the identification-related complications that the internal ratingsbased (IRB) approach (in its foundation or advanced version), usually adopted by large banks, brings. Under the IRB approach, banks' internal counterpartyrisk assessments, which are proprietary and hence typically not accessible to researchers, tend to differ across institutions in the capital charges that they imply for a given on- or off-balance sheet position (see, e.g., Financial Times 2013) 8 In contrast, the components of the standardized approach of Basel II are public knowledge. For us, this means that the same set of identification schemes applies to all banks operating in Turkey as of July 1, 2012.

The adoption of Basel II rules resulted in changes in the cost of capital, including capital charges for holding letters of credit, for banks in Turkey. The latter are off-balance sheet positions, where the cost of capital is calculated as the notional amount of the letters of credit multiplied by a credit conversion factor and then a risk weight. When Turkey moved from Basel I to the standardized approach of Basel II, the letters-of-credit-related risk weights changed depending on the agency rating of the letter of creditissuing counterparty bank's rating, while the credit conversion factors remained constant 9 As a result, the costs for Turkish banks to hold these instruments (for their Turkish exporter clients) were affected with the adoption of Basel II.

The move from Basel I to II generated two sets of risk weight changes for banks that hold export letters of credit. Under Basel I, for a counterparty bank located in an OECD-member country, the risk weight is 0.20 , while it is 1.00 for counterparties located in non-OECD countries. In contrast, under the standardized approach of Basel II, the risk weights differ (regardless of the country in which the counterparty bank is located) based on (1) the national regulator-defined groups of agency-rating categories following the Bank for International Settlements (BIS) guidelines and (2) the remaining maturity of the letters of credit (less than or greater than three months). As described in Table 1 these changes in risk weights, when combined with the simpler standard under Basel I, generate testable implications with opposite signs based on whether Turkish exports are destined for an OECD-member country and depending on the agency rating of the counterparty bank. Our empirical approach tests for changes in exports following the increases or decreases in the costs of letters of credit (given the counterparty institutions' agency ratings).

7 Starting on January 1, 2014, Turkey adopted Basel III, which is being implemented in stages until 2020.

8 Turkish banking authorities made it clear that the IRB approach eventually would be introduced and asked the banks in their jurisdiction to develop their own internal models. But, as of July 2013, no Turkish bank was permitted to use the IRB approach officially.

9 Under Basel I and II, the credit conversion factors can differ by $20 \%, 50 \%$, or $100 \%$ across the types of binding letters of credit that require a payment. But they remain fixed per letter of credit category during period we study. See the Internet Appendix Table A1. 
Table 1

Basel I and Basel II risk weights applied to off-balance sheet commercial letters of credit

Risk weights based on long-term agency ratings

Basel I

Basel II

\begin{tabular}{|c|c|c|c|c|c|}
\hline \multicolumn{2}{|c|}{ Risk weights } & \multicolumn{2}{|c|}{ Risk weights } & \multicolumn{2}{|c|}{ Agency rating categories } \\
\hline 1 & 2 & 3 & 4 & 5 & 6 \\
\hline OECD & Non-OECD & $\begin{array}{l}\text { Letter of credit } \\
\text { maturity } \\
<3 \text { months } \\
\text { (in case original } \\
\text { short-term ratings } \\
\text { do not exist) }\end{array}$ & $\begin{array}{l}\text { Letter of } \\
\text { credit } \\
\text { maturity } \\
>3 \text { months }\end{array}$ & Moody's & Fitch or S\&P \\
\hline 0.20 & 1.00 & $\begin{array}{l}0.20 \\
0.50 \\
1.50 \\
0.20\end{array}$ & $\begin{array}{l}0.20 \\
0.50 \\
1.00 \\
1.50 \\
0.50\end{array}$ & $\begin{array}{l}\text { Aaa to Aa3 } \\
\text { A1 to Baa3 } \\
\text { Ba1 to B3 } \\
\text { Caa1 and below } \\
\text { Non-rated (NR) }\end{array}$ & $\begin{array}{l}\text { AAA to AA- } \\
\text { A+ to BBB- } \\
\text { BB+ to B- } \\
\text { CCC+ and below } \\
\text { Non-rated (NR) }\end{array}$ \\
\hline
\end{tabular}

This table presents the Basel I and Basel II risk weights applied to foreign bank liabilities held by the Turkish banks for a given credit rating, including confirmed export-related commercial letters of credit issued by banking institutions domiciled in other countries.

Our dependent variable, Trade-credit export share, is defined as the ratio of letters-of-credit-based exports at the firm-product-country level to total exports (regardless of financing type) along the same dimensions. By construction, Trade-credit export share allows us to implicitly account for the country-level demand for a particular product of a given firm. This approach also accounts for subtler effects, such as differences in demand due to product quality that could vary by destination country for a given exporter (e.g., Manova and Zhang 2012).

We hypothesize that, holding everything else constant, Trade-credit export share would decrease (increase) as the associated letters of credit risk weights go up (down), compared to the cases in which no such change in risk weights occurs. The channels behind these hypothesized export share movements involve pricing and/or credit-exposure limit effects. The first channel would arise if Turkish banks pass on the higher (lower) cost of capital to their exporter clients. As the associated risk weight increases (decreases), holding the related letter of credit would cost more (less) for the bank, compared to cases in which the risk weights do not change. The second channel would arise if Turkish banks adopt credit-exposure limits as a simple risk-management tool. For example, after the change in risk weights instituted by Basel II, a Turkish bank could decide to have less counterparty bank exposures in the A1 to Baa3 rating range. Under this scenario, Turkish banks might decide to ration (or ration to a smaller degree) holding letters of credit issued by such counterparties given the changes in cost of bank capital. Such counterparty exposure limits would also affect the letters-of-credit-based export shares. Unfortunately, we have no way of empirically differentiating between these two not mutually exclusive channels. We call these two possible mechanisms the "international trade finance channel." 
To provide a more concrete description of our identification, suppose that a Turkish bank receives a request from a Turkish exporter to clear (i.e., hold as an off-balance sheet item) an export letter of credit of $\$ 1$ million (approximately equal to 1.8 million Turkish Liras on July 2, 2012) issued by the importer's bank and with a remaining maturity of more than three months. Prior to July 1 , 2012, under Basel I, for all counterparty banks located in an OECD-member country, the related risk weight was 0.20 . This would mean that holding this export letter of credit would have required the Turkish bank to set aside $\$ 24,000$ in additional capital, regardless of the risk of the counterparty bank issuing the letter of credit (as depicted in Column 1 of Table 110 After July 1, 2012, under the standardized approach of Basel II, the capital charge for the same letter of credit would depend on the OECD-based counterparty bank's agency rating (Column 4 of Table 1). Suppose that the counterparty bank rating is between A1 and Baa3 according to Moody's (A+ to BB- according to S\&P or Fitch) or is nonrated 11 The corresponding risk weight would increase from 0.20 to 0.50 . As a result, the capital that the Turkish bank needs to set aside to hold the letter of credit would go up to $\$ 60,000$, a $150 \%$ increase. Such transactions form our treatment group: We expect the bank to reflect this higher cost in its pricing for the service or maybe ration holding such letters of credit with higher capital charges. Alternatively, the agency rating for the counterparty bank could be in the Aaa to Aa3 range according to Moody's (AAA to AA- according to S\&P or Fitch). Then the capital charge would remain equal to $\$ 24,000$ as the associated risk weight would remain equal to 0.20 after adoption of Basel II. The latter forms the base-case (control) group in our regressions.

If, instead, the counterparty bank is located in a non-OECD country, identification would be driven by decreases in risk weight from 1.00 (Column 2 of Table 1 to 0.20 or 0.50 (Columns 3 and 4 of Table 1) as our non-OECD data are limited to investment grade rating classes. As the cost of holding a letter of credit from investment-grade counterparty banks decreases, we expect the related Trade-credit export share to increase.

Because we cannot trace the identities of the issuing banks in the data available to us, in our testing of the above hypotheses, we proxy the counterparty bank rating by the country-level (bank total asset weighted) average agency rating of all banks for which such ratings are available (more details are provided in Sections 1.2 and 1.3.

$10 \$ 24,000=\$ 1,000,000 \times 1.00 \times 0.20 \times 0.12$, where the credit conversion factor is equal to $100 \%$ (for a confirmed export letter of credit), the risk weight is equal to 0.20 (for an OECD counterparty under Basel I), and the minimum Tier $1+$ Tier 2 capital ratio is equal to $12 \%$ (as required by the Turkish banking regulators).

11 While it might seem initially counterintuitive, the Basel Committee recommends applying the same risk weight for nonrated bank counterparties as the risk weight for lower investment-grade bank counterparties (see Table 1 for details). This is done to foster imports for low-income countries that would otherwise be at a disadvantage due to the typically nonrated status of their financial institutions (BIS, October 2011). The Basel Committee also suggested the removal of the sovereign floor for the same reasons. 


\subsection{Empirical specifications}

To conduct our analysis, we estimate difference-in-differences models that are saturated with fixed effects. Our dependent variable is the first-differenced share of letters-of-credit-based exports. We rely on first-differencing for two reasons: First, it allows us to absorb any remaining firm-country-product-level confounding factors, so long as they stay constant over two consecutive annual periods. Second, and more importantly, as discussed at the end of Section 1.4, the standard difference-in-differences assumptions regarding the trend of the dependent variable being the same (on average) for both the treated and control groups does not hold for the OECD and non-OECD samples. To properly deal with this problem, we follow Khandelwal, Schott, and Wei 2013) and estimate the "triple-differences" models: We use three periods of annual data, which, when first-differenced, allow us to run a difference-in-differences model with a two-period panel of differenced observations for the same firm-countryproduct triplet. The resultant specifications capture the same treatment effect as a difference-in-differences model in the levels of the dependent variable, but allow for differences in pretreatment trends for the treated and the control groups (e.g., Mora and Reggio 2013; Lee 2016).

First, let's consider the difference-in-differences regression for the OECD sample, which corresponds to the identification scheme that involves a move from Column 1 to Column 4 of Table 1 .

$$
\begin{aligned}
\Delta \text { Trade-credit export share }_{f, c, p, t}= & \beta_{1} . \text { Risk-weight increase } e_{c} \times \text { Basel II }_{t} \\
& +\gamma_{c, p}+\gamma_{p, t}+\varepsilon_{f, c, p, t},
\end{aligned}
$$

where $\Delta$ denotes the first-difference operator (such that $\Delta x_{t}=x_{t}-x_{t-1}$ ); Tradecredit export share $_{f, p, c, t}$ is defined as the ratio of letters-of-credit-based exports for firm $f$ exporting a six-digit Harmonized System (HS6 level) product $p$ to destination country $c$ in period $t$ with respect to total exports (along the same dimensions but inclusive of all types of export financing); subscript $t \in$ $\{1,2\}$ denotes annual periods in the two-period panel with first-differenced dependent variable, where $t=1$ covers July 1, 2011 through June 30, 2012, and $t=2$ corresponds to July 1,2012 through June 30, 2013 ( $t=0$, which is implicit in the first differencing for $t=1$, covers July 1, 2010 through June 30, 2011); Riskweight increase $e_{c}$ is an indicator variable equal to one if the risk weight for letters of credit increase from 0.20 to 0.50 following the adoption of Basel II, and zero otherwise; Basel $I I_{t}$ is equal to one for $t=2$, and zero otherwise; $\gamma_{c, p}$ and $\gamma_{p, t}$ denote country $\times$ product and product $\times$ time fixed effects, respectively; and $\varepsilon$ is the error term of the OLS regression. In Equation (1) (and also in Equations (2) and (3)), the coefficient estimates for the stand-alone indicator variables Risk-weight increase $_{c}$ (Risk-weight decrease in $_{\text {) }}$ ) and Basel $I_{t}$ are absorbed into $\gamma_{c, \mathrm{p}}$ and $\gamma_{p, \mathrm{t}}$ fixed effects, respectively. Risk-weight increase . $_{c}$ tracks the cases that correspond to the letter of credit-issuer counterparty bank in the destination OECD country $c$ that have, on average, and throughout our sample, a long-term 
credit rating between A1 to Baa3 according to Moody's (or equivalently, A+ to BBB- according to S\&P or Fitch) or, alternatively, if none of them are rated. For these rating categories for the counterparty banks, the associated risk weights increase by $150 \%$. As a result, the letter of credit channel of trade hypothesis suggests that $\beta_{1}$ is negative. The omitted (i.e., the base case) category comprises exports for which the risk weight is 0.20 under both Basel I and II; that is, the base case involves letters of credit issued by counterparty banks with (countrylevel) average ratings between Aaa to Aa3 according to Moody's (AAA through AA- according to S\&P or Fitch). The empirical model does not include rating categories below Baa3. This is because there are no OECD countries with banks that have an average agency rating equal to Caa1 or worse throughout the sample period, and only two countries have banks that are consistently rated Ba1 to B3 (see Section 1.4 12

We estimate a similar model for the non-OECD sample:

$$
\Delta \text { Trade-credit export share }_{f, c, p, t}=\beta_{1} \text {. Risk-weight decrease }{ }_{c} \times \text { Basel II }
$$

$$
+\gamma_{c, p}+\gamma_{p, t}+\varepsilon_{f, c, p, t}
$$

where Risk-weight decrease cis $_{\text {in }}$ andicator variable equal to one if the letter of credit issuing counterparty banks have, on average, at the country level, investment-grade (Aaa-Baa3 or equivalently AAA-BBB-) ratings throughout the sample period, and zero otherwise 13 and the remaining variables are

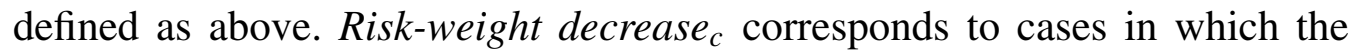
risk weights drop from 1.00 under Basel I to either 0.20 or 0.50 under Basel II, under the assumption that the letters of credit have, on average, remaining maturities longer than three months 14 The base case involves Ba1- to B3-rated counterparties according to Moody's for which risk weight is constant at 1.0. The expected sign of the coefficient estimate of interest $\beta_{1}$ is now positive: We expect letters-of-credit-based export shares to go up as the costs of holding these instruments go down with Basel II.

We could improve on the estimates of Equations (10) and (2) by pooling the OECD and non-OECD samples. This is because, given the very large number of fixed effects in our empirical models, combining the two samples allows us to preserve degrees of freedom, leading to more efficient estimation. We define

12 This effectively constrains OECD regressions to the case for which the remaining maturities of letters of credit are longer than three months (please refer to Table 1 Columns 1 and 3 versus 4 ).

13 We combine the Aaa-Aa3 category (for which the risk weight decreases from 1.00 to 0.20 ) with the A1-Baa3 category (for which the risk weight decreases from 1.00 to 0.50 ) because the former includes three marginal destinations for Turkish exports (Hong Kong, Malta, and Singapore) receiving between $0.22 \%$ and $0.60 \%$ of Turkish exports. In the Internet Appendix Tables A2 and A5, we provide additional regressions in which these two categories are accounted for separately.

14 Under the assumption that the letters of credit have, on average, remaining maturities shorter than three months, Risk-weight decrease $e_{c}$ corresponds to cases in which the risk weights drop from 1.00 under Basel I to 0.20 with Basel II. 
the regression equation for the pooled sample as

$\Delta$ Trade-credit export share ${ }_{f, c, p, t}=\beta_{1}$. Risk-weight increase ${ }_{c} \times$ Basel $I_{t}$

$$
\begin{aligned}
& +\beta_{2} . \text { Risk-weight decrease }_{c} \times \text { Basel II }_{t} \\
& +\beta_{3} . \text { OECD } D_{c} \times \text { Basel II } t+\gamma_{c, p}+\gamma_{p, t}+\varepsilon_{f, c, p, t},
\end{aligned}
$$

where $O E C D_{c}$ is an indicator variable equal to one if the export-destination is an OECD-member country, and zero otherwise. The $O E C D_{c} \times \mathrm{Basel}_{t}$ interaction is needed here to capture the post-Basel II differences in the base cases (with the stand-alone $O E C D_{c}$ indicator variable being soaked up by country $\times$ product fixed effects).

While the above specifications (1) through (3) allow us to detect any changes in the letters-of-credit-based export shares following the adoption of Basel II, they cannot help us verify whether growth of overall exports was affected. Our hypotheses would suggest that changes in the costs of letters of credit could affect aggregate trade flows inclusive of all payment types. And any effect of Basel II adoption on overall exports would, of course, be more pronounced for firms with a higher usage of letters of credit before the adoption of Basel II. An alternative scenario would be the one under which firm-country-product-level overall exports would not be affected, because exporters would seek and obtain changes to export settlements by changing payment types (i.e., moving across letter of credit and non-letter-of-credit payment terms). We test for the effect of Basel II adoption on overall trade growth by running the following regression for the OECD sample:

$\Delta \ln ($ Total exports ex, $, p, t)=\beta_{1}$. Risk-weight increase i $_{c} \times$ Basel $I_{t}$

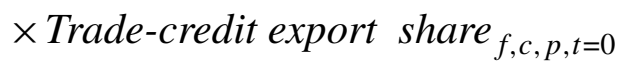

$+\beta_{2}$. Risk-weight increase $_{c}$

$\times$ Trade-credit export share $_{f, c, p, t=0}$

$+\beta_{3}$.Basel $\mathrm{II}_{t} \times$ Trade-credit export share $_{f, c, p, t=0}$

$+\beta_{4}$.Trade-credit export share ${ }_{f, c, p, t=0}+\gamma_{c, p, t}+\varepsilon_{f, c, p, t}$,

where $\ln$ (Total exports T,c,p,t $_{\text {) }}$ is the natural logarithm of the value of total exports of firm $f$ to country $c$ for a given product $p$; Trade-credit export share ${ }_{f, c, p, t=0}$ is the period $t=0$ (i.e., July 1, 2010 through June 30, 2011) share of letter of credit financed exports for firm $f$ to country $c$ for a given product $p$; and the other variables are defined as above. For the non-OECD sample, we define a 
similar growth regression equation:

$$
\begin{aligned}
\Delta \ln \left(\text { Total exports }_{f, c, p, t}\right)= & \beta_{1} \text { Risk-weight decrease }_{c} \times{\text { Basel } I I_{t}} \\
& \times \text { Trade-credit export share }_{f, c, p, t=0} \\
& +\beta_{2} \text { Risk-weight decrease } \\
& \times \text { Trade-credit export share }_{f, c, p, t=0} \\
& +\beta_{3} \text { Basel } I_{t} \times \text { Trade-credit export share }_{f, c, p, t=0} \\
& +\beta_{4} \text { Trade-credit export share } \text { ex, }, p, t=0_{c, p, t}+\varepsilon_{f, c, p, t},
\end{aligned}
$$

where all the variables are defined as above. In the next section, we describe the data used in estimating Equations (1) through (5).

\subsection{Data}

Our data come from two sources. Firm-country-product-trade-financing-level export flows data are obtained from the Turkish Statistical Institute (TSI) 15 Counterparty bank rating data are from Bankscope.

For the data needed to construct our dependent variable, Trade-credit export share, we proceed as follows with the TSI data. Given the Basel II adoption date of July 1, 2012, first we aggregate the monthly firm-country-producttrade-financing-level export flows data at the annual level. Each annual period, represented by $\mathrm{t} \in\{-1,0,1,2\}$, is defined from July 1 of year $\tau$ to June 30 of year $\tau+1$ with $\tau \in\{2009,2010,2011,2012\}$. In a second step, we construct our dependent variable as described in the previous section. Annual data based on periods $t=\{0,1,2\}$ are used in our main analysis. After we first-difference the dependent variable, we obtain a two-period panel with which we estimate our difference-in-difference regressions. Data based on periods $t=\{-1,0,1\}$ are used for placebo regressions.

Before proceeding further, we explain the reasoning underlying the abovedescribed choices. We aggregate monthly export flows into annual ones for the following reasons. First, we would like to attenuate the problems associated with zero-trade observations. Our dependent variable is the first-differences of letters-of-credit-based export share. This variable takes the value of zero when exporters use a type of financing other than letters of credit. Naturally, if there are no exports for a firm-country-product triplet in a given annual period, we cannot calculate the letters-of-credit-based share of exports. Moreover, given that we first-difference the dependent variable, we require that some

15 These confidential data are accessed through dedicated computers at the TSI offices upon a special request and after a security clearance: statistics and regression results can only be exported upon approval of the TSI staff. We underline the fact that the TSI data set has detailed export flows data but it has no export shipments data. 
exports, regardless of the trade financing method involved, be available in all annual periods for a firm-country-product triplet. With the monthly or quarterly observations, the requirement to have at least some exports in all periods would lead to the loss of most of the data at our disposal. Second, we would like to account for the seasonality of the trade flows. We do not want the interactions of the ratings range (i.e., risk weights) and Basel II indicator variables to pick up what could be, in essence, a seasonal variation in exports that arises at the monthly or quarterly frequency. Seasonality could also induce serial correlation in the panel, for which one solution is indeed the aggregation of the data at the annual frequency (e.g., Bertrand, Duflo, and Mullainathan 2004).

We combine the above-described TSI exports data with long-term agency ratings for counterparty banks. To do so, we collect all available ratings by Fitch, Moody's, and S\&P from the Bankscope database for individual financial institutions that could be issuing letters of credit for importer-clients of Turkish exporters 16 For many banks, we have overlapping ratings from more than one of these three agencies. In these cases, we follow the rules imposed by the Turkish banking regulators 18 If a foreign counterparty bank has two agency ratings, Turkish banks have to use the lower of the two ratings, and if it has three ratings, Turkish banks are required to use "the better of the worst two ratings" (i.e., the middle rating). Since the TSI data do not identify the letterof-credit-issuing institutions, we use a proxy for the counterparty-bank rating at the export-destination-country level. For this, we create a variable by weighting the observed bank ratings by the latest available total assets, as well as by the number of days the observed rating is valid for an institution (in case there are changes to that institution's ratings over the annual period), for a given country in a given annual period $t$. We weight the observed ratings by bank total assets for the following reasons. Some evidence suggests that a country's largest banks predominantly issue letters of credit: Del Prete and Federico 2014 note that the issuance of trade guarantees (which include letters of credit) is limited to the top-ten Italian banks, which issue $78 \%$ of export- and $74 \%$ of import-related loans, whereas Niepmann and Schmidt-Eisenlohn 2017) observe that top-five U.S. banks account for $92 \%$ of all U.S. trade claims (which, in their data, are mainly letters of credit, but also include other claims such as factoring and forfaiting). However, it is not clear to what extent Italy and the United States are representative of other OECD countries, let alone non-OECD countries. For example, for Turkey (an OECD-member country), bankers that we spoke

16 Alongside Fitch, S\&P and Moody's ratings, the Turkish regulator also allows ratings by JCR and DBRS agencies, but these institutions' ratings are not available in the Bankscope database.

17 These include commercial banks, bank holding companies, state-, local government- or privately-owned savings banks, credit unions, cooperative banks, specialized government credit institutions (which include export-import banks), Islamic banks, and micro-finance institutions. We exclude the ratings of the following types of institutions: central banks, supranational entities (e.g., regional development banks), securities firms, investment banks, investment and trust corporations, and finance companies.

18 As detailed in the BDDK Directive of June 28, 2012, Supplement 1, Section 2 Articles 1.5 and 1.6. 
to indicated that while the largest Turkish banks typically issue letters of credit, smaller foreign banks are also locally active in this business (most likely thanks to the comparative advantage conveyed by them being owned by a larger foreign bank). As a result, our proxy for counterparty-bank ratings allows us to account for the fact that the largest banks in a country are most likely to be the most common issuers of letters of credit, without ruling out the possibility that small, specialized banks operating in the export-destination country also might be involved in this line of business.

Before moving on to the summary statistics, we acknowledge that our data set, while very detailed on export flows, has some weaknesses. First, the TSI data do not contain any information on importers located in exportdestination countries: We cannot directly match exporters to their foreign importer-partners. That said, to the extent that the importer or group of importers in a given country to which a Turkish firm exports one particular product stays constant over two consecutive annual periods, any associated effects would be differenced-out in our empirical approach. Second, the TSI data do not contain any information regarding the letters of credit used in Turkish exports apart from the fact that the associated flows are financed with these instruments. As a result, we cannot observe the types or the maturities of the related letters of credit. Different types of letters of credit map into four different credit conversion factors. However, the latter remain constant under both Basel I and Basel II (see the Internet Appendix Table A1). As a result, our findings are driven by changes in risk weights with Basel II, and not credit conversion factors that remain constant (we nevertheless conduct a robustness check that limits the latter to a single credit conversion factor category). Third, the TSI data do not include any information about the Turkish banks that hold the letters of credit. That said, we can account for Turkish exporters' bank relations (1) if the composition of the latter remains constant over two consecutive annual periods (through firstdifferencing) or (2) any changes therein would be captured by time-varying firm fixed effects that we include in some of our specifications. Fourth, our data do not allow us to observe the identities of the counterparty banks (located in other countries) that have issued the letters of credit used in Turkish exports. As a result, we rely on a country-level proxy for the counterparty bank ratings described above. These limitations, which are imposed on us by the nature of the TSI data, inevitably put some restrictions on the analyses that we can conduct. They also point to the importance of saturating our empirical models with many fixed effects to absorb unobservables that otherwise might have confounding effects on our tests. In the next section, we present the summary statistics and discuss the trends of the data.

\subsection{Summary statistics}

Before going over the summary statistics, we explain a number of restrictions that we impose on the combined TSI-Bankscope data. First, we limit ourselves to shipments by the manufacturing sectors, which formed $94 \%$ of Turkish 
goods exported in 2012. Second, we exclude firm-country-product-level annual exports that are below $\$ 10,000$ to remove small shipments by marginal exporters that might otherwise influence our export share-based estimates. Third, to estimate proper difference-in-differences models, we need to ensure that the confounding factors are appropriately captured by the same set of constants throughout the estimation period. To accomplish this, and given that our counterparty-bank rating proxy is at the country level, we require that the indicator variables Risk-weight increase en $_{\text {isk-weight decrease }}$ oroperly capture the related firm-country-product-level observations (e.g., within Aaa$\mathrm{Baa} 3$ or A1-Baa3 rating ranges that correspond to different changes in risk weight) throughout our sample (see Table11). As a result, we exclude countries for which the counterparty-bank rating proxy moves across rating ranges as defined by Basel II (e.g., from Aaa-Aa3 range to A1-Baa3 for the OECD sample or between investment and non-investment-grade categories for the non-OECD sample), something which effectively fixes the credit ratings as of the pre-Basel II period. Fourth, we exclude a number of countries because they are specific cases that might otherwise have an undue influence on our results. These include countries that become OECD-members during our sample period, Cuba, socalled "Arab Spring countries," together with Iran and United Arab Emirates 19 After these restrictions, we are left with exports by 9,085 $(11,419)$ firms to 25 (133) OECD (non-OECD) countries in 2,140 (2,661) HS6 product categories. The data in our final sample correspond to about $56 \%$ of Turkey's manufacturing exports for the July 2011-June 2013 period by value.

Table 2 provides summary statistics for our dependent variable for the two annual periods ( $t=1$ and $t=2$ ) around the adoption date of July 1, 2012. In panel A, for the OECD sample, the average share for letters-of-credit-based exports is equal to 0.0363 and 0.0343 in the pre- and post-Basel II period, respectively. The observed difference of 0.0030 is statistically different from zero at the $10 \%$ level in a two-sided $t$-test. For the non-OECD sample, the average share for letter of credit-based exports is equal to 0.0584 before Basel II adoption and to 0.0550 after the application of the new rules. The difference of 0.0034 in the export shares is statistically different from zero at the $1 \%$

19 Barbados, Belize, Grenada, Luxembourg, Pakistan, and Uruguay are excluded because the related weightedaverage bank rating moves across rating-range (risk-weight) categories. Chile, Estonia, Israel, and Slovenia are excluded because these countries became OECD-members in 2010, during our sample period. Greece is excluded from the OECD sample because (1) it is the only country with near-default ratings, and (2) during the period studied, the proxies for its banks' ratings (in terms of total assets-weighted average bank rating), although constant in mean (near default, with a 1.50 risk-weight category), change dramatically between categories. Hungary and Portugal are also excluded for a similar reason: (1) both would be the only countries in the "junk" category with very few observations, (2) although their yearly mean rating puts them in the speculative range (a 100\% risk-weight category), the sovereign ratings worsen dramatically from the A1-Baa3 range according to Moody's to speculative grade. Cuba has no rated banks but is the only non-OECD country in sovereign default status throughout the sample period and a marginal export destination. Arab Spring countries' imports as well as their banks' credit ratings were negatively affected by social unrest and civil wars during our sample period. We drop Iran because it was subjected to an international embargo, which led to an increase in gold trade with Turkey to get around sanctions Dombey 2013). We also eliminate United Arab Emirates because most of the unusual Turkish-Iranian gold transactions appear to have gone through this country Dombey and Guler 2013). 
Table 2

Summary statistics for the dependent variable

A. Trade-credit export share at the firm-country-product level by annual period

\begin{tabular}{|c|c|c|c|c|c|}
\hline \multicolumn{2}{|c|}{ OECD sample } & \multirow[b]{2}{*}{$t$-stat } & \multicolumn{2}{|c|}{ Non-OECD sample } & \multirow[b]{2}{*}{$t$-stat } \\
\hline $7.1 .2011-6.30 .2012$ & $7.1 .2012-6.30 .2013$ & & $7.1 .2011-6.30 .2012$ & $7.1 .2012-6.30 .2013$ & \\
\hline $\begin{array}{l}0.0363 \\
(0.1633) \\
{[47,183]}\end{array}$ & $\begin{array}{c}0.0343 \\
(0.1614) \\
{[47,183]}\end{array}$ & $1.83^{*}$ & $\begin{array}{c}0.0584 \\
(0.2147) \\
{[63,040]}\end{array}$ & $\begin{array}{l}0.0550 \\
(0.2101) \\
{[63,040]}\end{array}$ & $2.79 * * *$ \\
\hline
\end{tabular}

$B$. Trade-credit export share at the firm-country-product level by annual period and by risk-weight changes

that correspond to agency rating ranges

\begin{tabular}{|c|c|c|c|c|c|c|c|}
\hline \multicolumn{4}{|c|}{$\begin{array}{c}\text { OECD sample } \\
\text { (letter of credit maturities }>3 \text { months) }\end{array}$} & \multicolumn{4}{|c|}{$\begin{array}{c}\text { Non-OECD sample } \\
\text { (letter of credit maturities }<3 \text { months) }\end{array}$} \\
\hline $\begin{array}{l}\text { Risk-weight change } \\
\text { (Moody's ratings range) }\end{array}$ & $7.1 .2011-6.30 .2012$ & $7.1 .2011-6.30 .2013$ & $t$-stat & $\begin{array}{l}\text { Risk-weight change } \\
\text { (Moody's ratings range) }\end{array}$ & $7.1 .2012-6.30 .2012$ & $7.1 .2012-6.30 .2013$ & $t$-stat \\
\hline $\begin{array}{l}\text { Risk-weight unchanged } \\
\text { at } 0.20 \\
\text { Aaa-Aa3 / AAA-AA-) }\end{array}$ & $\begin{array}{c}0.0130 \\
(0.1010) \\
{[13,375]}\end{array}$ & $\begin{array}{c}0.0118 \\
(0.0970) \\
{[13,375]}\end{array}$ & 0.97 & $\begin{array}{l}\text { Risk-weight decrease } \\
\text { from } 1.00 \text { to } 0.20 \text { or } 0.50 \\
\text { (Aaa-Baa3 / AAA-BBB- } \\
\text { or nonrated) }\end{array}$ & $\begin{array}{c}0.0736 \\
(0.2399) \\
{[39,044]}\end{array}$ & $\begin{array}{c}0.0705 \\
(0.2371) \\
{[39,044]}\end{array}$ & $1.78 *$ \\
\hline $\begin{array}{l}\text { Risk-weight increase } \\
\text { from } 0.20 \text { to } 0.50 \\
\text { (A1-Baa3 / A+-BBB- } \\
\text { or nonrated) }\end{array}$ & $\begin{array}{c}0.0455 \\
(0.1813) \\
{[33,808]}\end{array}$ & $\begin{array}{c}0.0433 \\
(0.1799) \\
{[33,808]}\end{array}$ & 1.61 & $\begin{array}{l}\text { Risk-weight unchanged } \\
\text { from } 1.00 \text { to } 0.50 \\
\text { (Ba1-B3 / BB+-B-) }\end{array}$ & $\begin{array}{c}0.0337 \\
(0.1629) \\
{[23,996]}\end{array}$ & $\begin{array}{c}0.0299 \\
(0.1532) \\
{[23,996]}\end{array}$ & $2.63 * * *$ \\
\hline
\end{tabular}

Panel A presents the means for Trade-credit export share, the dependent variable, in the annual periods around the Basel II adoption date of July 1, 2012. The standard deviations are within parentheses, and the number of observations are within brackets. Panel B presents the same statistics by rating categories that correspond to different risk weights, some of which are subject parentheses, and the number of observations are within brackets. Panel B presents the same statistics by rating categories that correspond to different risk weights, some of which are subject
to change with Basel II's adoption in Turkey. $t$-statistics are provided for two-sided tests, which allow for unequal variances, of the equality of the mean of letter-of-credit-based share of to change with Basel II's adoption in Turkey. $t$-statistics are provided for two-sided tests,
exports. *, $* *$, and $* * *$ indicate significance at the $10 \%, 5 \%$, and $1 \%$ level, respectively. 
level in a two-sided $t$-test. Notably, these means are based on firm-countryproduct-level share of exports. In fact, our raw data (based on value of exports) exhibit patterns similar to those reported in the literature for other countries: When aggregated over firms-products-destination countries, the (value-based) fraction of Turkish trade that relies on letters of credit is approximately 5\% for the OECD countries and roughly $15 \%$ for the non-OECD countries 20

In fact, our export share data exhibit heterogeneity in many dimensions. One of these is the difference in the use of letters of credit across counterparty rating groups that form our "treatment" and control groups (based on the associated risk-weight categories). In panel B of Table 2, we provide the average share of letters-of-credit-based exports for counterparty-bank rating ranges that correspond to categories of risk weights at the heart of our identification schemes. For the OECD sample, for countries with banks rated between AaaAa3 on average (and for which the corresponding risk weight stays constant at 0.20 ), the average share of exports is 0.0130 in the year prior to adoption of Basel II and 0.0118 in the year after (the difference of 0.0012 is not statistically significant in a $t$-test). For countries with institutions that are, on average, rated A1-Baa3 or are nonrated (which correspond to our test variable, Riskweight increase $_{c}$, and for which the risk-weight increases from 0.20 to 0.50 ), the average share of exports decreases from 0.0455 pre-Basel II to 0.0433 postBasel II (the difference of 0.0022 is marginally statistically significant at $11 \%$ in a two-sided $t$-test that allows for unequal variances). For the non-OECD sample, we see a larger share of exports based on letters of credit for higherrated counterparties. For countries with banks that are investment-grade rated on average (for which the risk weights drop from 1.00 to 0.20 or 0.50 ), the average share of exports is approximately 0.0736 pre-Basel II versus 0.0705 post-Basel II (the difference is statistically significant at the $10 \%$ level). A decrease also can be observed for countries with Ba1-B3 rated counterparty banks (even though the related risk weight remains unchanged at 1.00) the average share of letters-of-credit-based exports is equal to 0.0337 pre-Basel II and 0.0299 post-Basel II (0.0038 difference is statistically significant at the $1 \%$ level in a two-sided $t$-test). While the observed decreases for the nonOECD sample appear counterintuitive (given that risk weights also decrease), they are most likely due to confounding factors that are not controlled for in these univariate statistics. For example, some of the observed patterns could be due to variations in the exports to different OECD countries by different

20 For example, Ahn 2014) states that letters of credit are involved in 5\% of Columbian and 10\% Chilean imports in 2011. Korean International Trade Association data indicate that $15 \%$ of South Korean exports involved letters of credit in 2012 (http://www.kita.net/statistic/index_eng.jsp). Niepmann and Schmidt-Eisenloht 2017) report that $9.6 \%$ of U.S. goods exports (in terms of value) were settled this way. International Credits and Collections Survey conducted by the Finance, Credit and International Business Association (FCIB) indicates that in 2010, the exporter-reported country-level use of letter of credit as the main payment method has an average of $10.8 \%$ for a sample of 59 countries (Table1 in Schmidt-Eisenlohr 2013). Antras and Foley 2015) report that 6\% of the exports of a large U.S. frozen-poultry products producer are letters of credit based. 
Table 3

Additional sample statistics: Industry breakdown

\begin{tabular}{lccc} 
Industry name & HS2 code & \multicolumn{2}{c}{ Letters-of-credit-based exports (in \%) } \\
\hline & & July $2011-$ June 2012 & July 2012-June 2013 \\
\hline Textiles & $50-63$ & 19.80 & 19.71 \\
Metals & $72-83$ & 17.41 & 15.98 \\
Machinery / electrical & $84-85$ & 16.48 & 15.52 \\
Transportation & $86-89$ & 13.35 & 12.25 \\
Stone / glass & $68-71$ & 9.63 & 12.79 \\
Plastics / rubbers & $39-40$ & 5.84 & 5.60 \\
Food & $16-24$ & 4.79 & 4.75 \\
Chemicals and allied industries & $28-38$ & 4.16 & 4.29 \\
Mineral products & $25-27$ & 2.96 & 3.19 \\
Miscellaneous & $90-97$ & 2.93 & 3.44 \\
Wood and wood products & $44-49$ & 1.57 & 1.36 \\
Raw hides, skins, leather and furs & $41-43$ & 0.65 & 0.62 \\
Footwear / headgear & $64-67$ & 0.42 & 0.49 \\
\hline
\end{tabular}

This table presents the letters-of-credit-based exports by industry for the two annual periods around the Basel II adoption date of July 1, 2012. Statistics based on the value of exports at the two-digit Harmonized System (HS2) industry level.
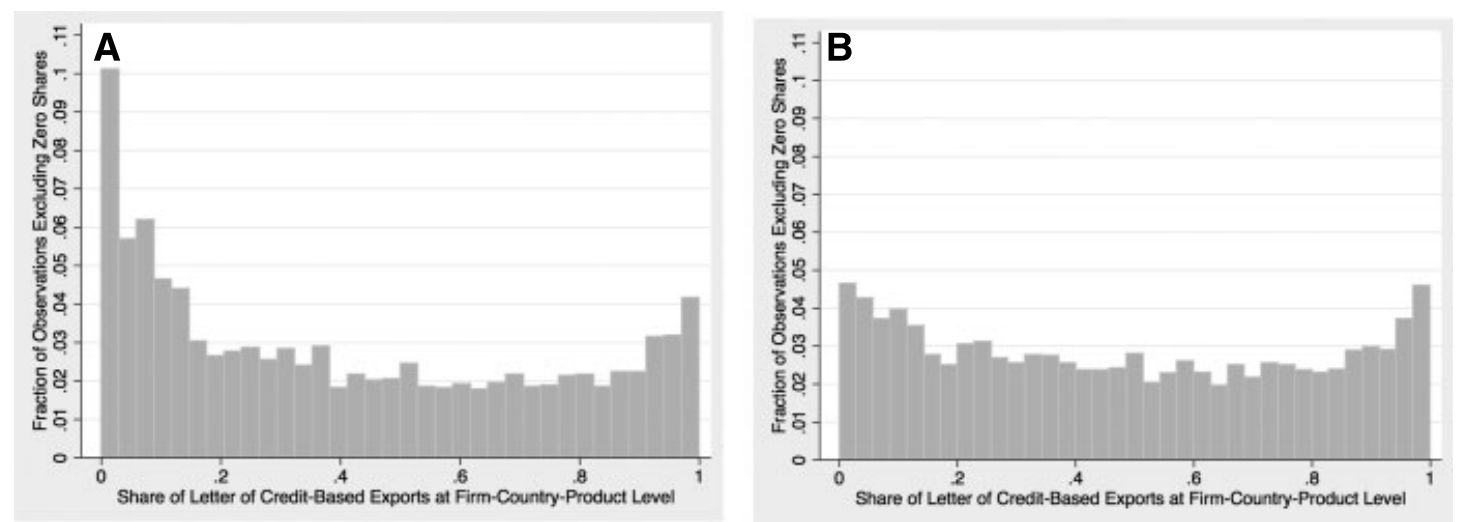

Figure 1

Pre-"treatment" (Basel II adoption) distribution of share of letters-of-credit-based exports at the firmcountry-product level

Figure $1 \mathrm{~A}$ plots, for the OECD sample, the frequency distribution of the share of letters-of-credit-based exports at the firm-country-product level in the annual period preceding the Basel II adoption date of July 1, 2012 (i.e., July 1, 2011 - June 30, 2012) and after excluding observations for which the share of exports is zero. Figure 1B does the same for the non-OECD sample.

industries, some of which might rely on letters of credit more than others (see, e.g., Table 3.

To get a further understanding of the variation in our dependent variable, in Figure 1 we provide the frequency distributions for the share of exports based on letters of credit after excluding the zero shares in the annual period $(t=1)$ that precedes the adoption of Basel II 21 In Figure 14 for the OECD sample, slightly more than $4 \%$ of the nonzero export share observastions have

21 This exclusion is done to facilitate the reading of the frequency distributions: in the annual period $t=1$ immediately preceding the adoption of Basel II, the percentage of observations for which the letter of credit share of exports is equal to zero is $92.8 \%$ for the OECD sample and $91.1 \%$ for the non-OECD sample. 
an export share of $100 \%$, suggesting that relatively few firms export a product to a destination country using letters of credit alone. In fact, for the OECD countries the frequency of lower use of letters of credit (related share of exports less than 10\%) is more common (ranging from $5 \%$ to $10 \%$ of the distribution) than higher use (share of export higher than 90\%) of these instruments (ranging from approximately $2 \%$ to $4 \%$ ). In Figure 1B for the non-OECD sample, the frequency distribution of nonzero share of letters-of-credit-based exports is more evenly distributed (between $2 \%$ and $5 \%$ ).

In Table 3 we provide statistics on the heterogeneity of export financing across industries, albeit at the level of groups of HS2-level industries for the ease of exposition (given that we have 2,888 HS6-level products in the data). For example, in the year preceding the adoption of Basel II (i.e., during $t=$ 1 ), the letter of credit-financed exports account for only $0.42 \%$ of exports in the footwear and $0.65 \%$ in the "raw hides, skins, leather and furs" sectors, in contrast to $16.48 \%$ in the machinery industries, $17.41 \%$ in metals, and $19.80 \%$ in textiles.

To get a better sense of the heterogeneity observed in the data, in Table 4 we provide more information on the variation of the export patterns per firm, country, HS6-level product type, and combinations thereof, in the annual period prior to the adoption of Basel II (i.e., in $t=1$ ). For example, in panel A of Table 4 for letters of credit based exports to OECD countries, the average (median) of number of exporters per country is 66.3 (39), products per exporter 2.4 (1), products per country 72.8 (37), exporters per country-product pair 1.9 (1), products per exporter-country pair 2.0 (1), and export-destination countries per firm-product pair 1.4 (1). In panel B of the same table, we observe similar patterns along these dimensions for the non-OECD sample. The statistics presented in Table 4 underline the importance of controlling for heterogeneity inherent in the exports data.

The above observed differences in the use of letters of credit for the financing of international trade are likely to depend on many firm characteristics, some of which may be directly observable (e.g.. industry segment like in Hoefele, Schmidt-Eisenlohr, and Yu 2016), others adequately proxied by measurable firm characteristics (e.g., firm size) or simply unobservable (e.g., the bargaining power of the firm in negotiating with its importers like in Demir and Javorcik 2014). Some of the observed heterogeneity might reflect unobservable qualities of the exported good (for example, the same manufacturer can ship different quality versions of the same product to two different destination countries like in Manova and Zhang 2012). Given the limitations of the data at our disposal, we do not resort to Heckman-type selection models to adjust for the presence of unobservable characteristics at various levels, but instead we rely on firstdifferences to absorb confounding factors at the firm-country-product level 22

22 Put differently, any Heckman-type firm-level selection correction that would be introduced in our export share regressions would be differenced-out in our baseline regressions at the firm-country-product level. 
Table 4

Additional sample statistics: Firm, country, and product breakdown

A. OECD sample

\begin{tabular}{|c|c|c|c|c|c|c|c|c|}
\hline \multirow[b]{2}{*}{ Total number } & \multicolumn{4}{|c|}{ Letter-of-credit-financed exports } & \multicolumn{4}{|c|}{ Nonletter of credit financed exports } \\
\hline & $\mathrm{N}$ & Mean & $\mathrm{Sd}$ & Median & $\mathrm{N}$ & Mean & SD & Median \\
\hline Firms per country & 25 & 66.28 & 90.83 & 39 & 25 & 935 & 924.28 & 645 \\
\hline Products per firm & 996 & 2.38 & 3.64 & 1 & 8,900 & 2.47 & 4.02 & 1 \\
\hline Products per country & 25 & 72.76 & 83.22 & 37 & 25 & 526.64 & 355.17 & 445 \\
\hline Firms per country-product pair & 1,819 & 1.86 & 3.05 & 1 & 13,166 & 3.33 & 7.77 & 1 \\
\hline Products per firm-country pair & 1,657 & 2.04 & 2.73 & 1 & 23,375 & 1.87 & 2.65 & 1 \\
\hline Countries per firm-product pair & 2,371 & 1.43 & 1.12 & 1 & 21,962 & 1.99 & 2.20 & 1 \\
\hline \multicolumn{9}{|l|}{ B. Non-OECD sample } \\
\hline Firms per country & 105 & 32.03 & 63.97 & 13 & 133 & 214.23 & 430.44 & 41 \\
\hline Products per firm & 1,746 & 1.88 & 2.28 & 1 & 11,009 & 2.93 & 8.05 & 1 \\
\hline Products per country & 105 & 36.28 & 64.05 & 16 & 133 & 169.43 & 267.73 & 48 \\
\hline Firms per country-product pair & 3,809 & 1.47 & 2.30 & 1 & 22,534 & 2.55 & 4.43 & 1 \\
\hline Products per firm-country pair & 3,363 & 1.66 & 1.73 & 1 & 28,492 & 2.02 & 5.03 & 1 \\
\hline Countries per firm-product pair & 3,286 & 1.70 & 2.29 & 1 & 32,240 & 1.78 & 2.38 & 1 \\
\hline
\end{tabular}

This table presents statistics on the various dimensions of the data. $\mathrm{N}$ is the number of observations. Statistics are based on data from July 1, 2011 to June 30, 2012, that is, for the annual period prior to the adoption of Basel II.

Next, we focus on the time-trends in our dependent variable across counterparty rating groups corresponding to risk weights at the core of our identification strategy. We would like to test the effects of changes in the risk weights (hence the cost of capital) for letters of credit on the shares of lettersof-credit-based exports using the difference-in-differences approach based on the interactions between rating-range and Basel II indicator variables. Such an approach requires that the basic difference-and-differences assumption holds in our data: that is, the pretreatment paths of the share of letters-of-credit-based exports should be similar across rating-range group for which the risk weights change (the treated group) with Basel II compared to that for which they remain the same (the control group). To examine whether this is the case, first we plot the average share of letter of credit based exports (at the firm-country-product level) for counterparty rating ranges that correspond to risk weights listed in Table 1 Figure 2 shows, and additional tests confirm (see Internet Appendix Table A6), that the basic difference-in-differences assumptions are unlikely to prevail in either of the two samples (OECD and non-OECD) that we use. There are pre-Basel II differences not only in the levels of share of exports (which would be absorbed by the related rating-range indicator variables), but more importantly, in the trends of share of letters-of-credit-based exports between the treated groups and control groups 23 These observations suggest that our

23 The observed differences in time-trends may arise, at least in part, due to the fact that Turkish banks were asked to conduct Basel II Quantitative Impact Studies (QIS) by the Turkish regulators, as suggested by the Basel Committee (e.g., BDDK Report, July 2007). These QIS would have drawn the banks' attention to various costs associated with the adoption of Basel II: Banks might have started to implement some, if not most, of the policy changes triggered by Basel II earlier than the adoption date of July 1, 2012, potentially generating changes in time trends. We test for this possibility by conducting placebo regressions as part of our robustness checks in Section 3 . 

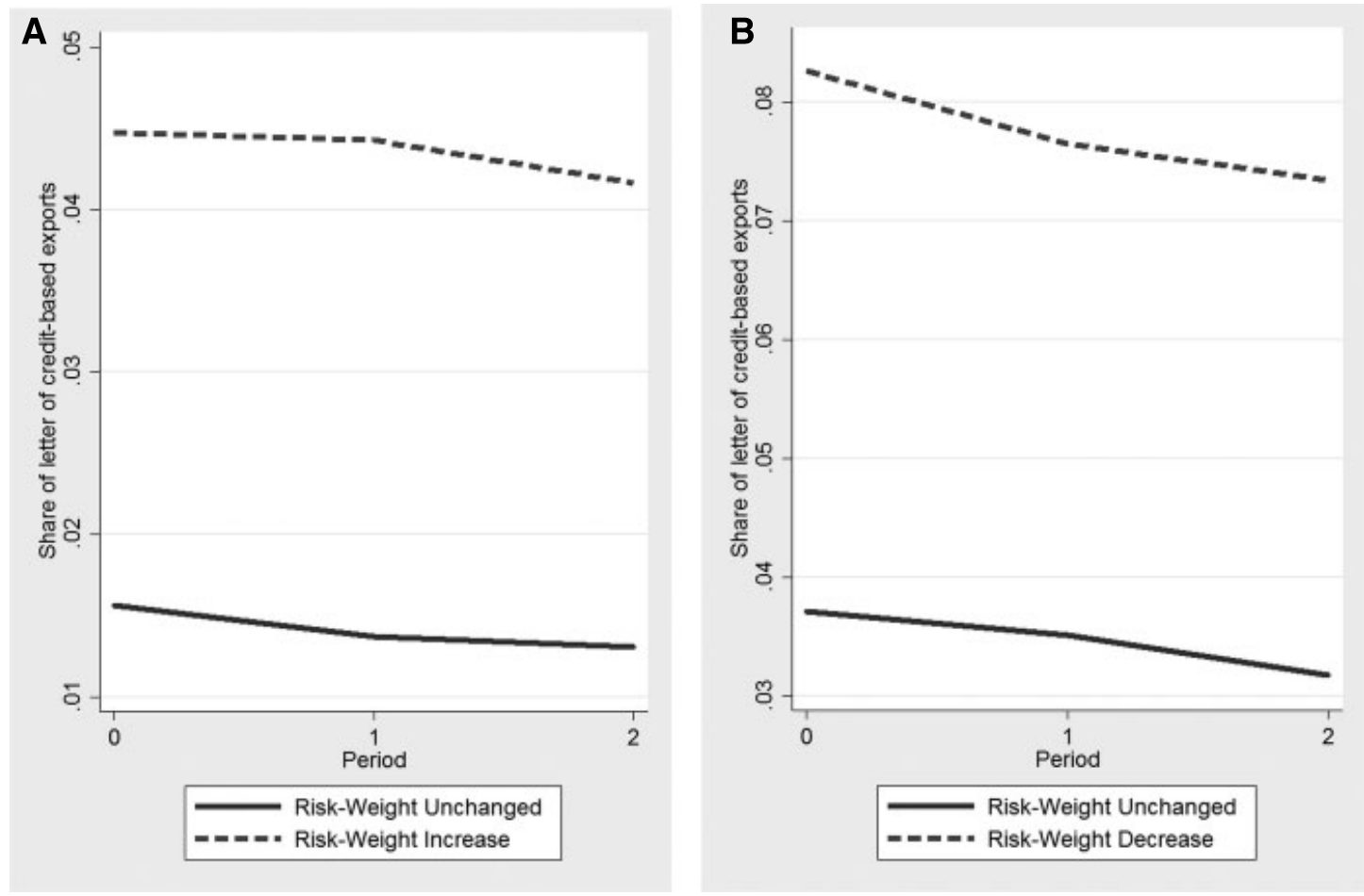

Figure 2

Pre- and post-"treatment" trends in letters-of-credit-based share of exports at the firm-country-product level

Figures $2 \mathrm{~A}$ and $2 \mathrm{~B}$ plot, for different annual periods, pre- and post-“treatment" (Basel II adoption) trends in letters-of-credit-based share of exports at the firm-country-product level for ranges of counterparty bank ratings that correspond to risk-weight categories defined by Basel II (and depicted in Table11. Pre-Basel II annual periods correspond to $t=0$ (July 1, 2010-June 30, 2011) and $t=1$ (July 1, 2011-June 30, 2012), whereas post-Basel II period is $t=2$ (July 1, 2012-June 30, 2013). Figure 2 A corresponds to the OECD sample used in the estimation of Equation 11. Figure 2B corresponds to the non-OECD sample used in the estimation of Equation 2 .

empirical approach has to take into account the differences in the time trends across the treatment and control groups for the letters-of-credit-based share of exports. We do so by following Khandelwal, Schott, and Wei 2013) and implement difference-in-differences with the first-differenced (rather than the level of) share of exports, as detailed in Section 1.2 24

\section{Main Results}

Before discussing the results, we note that the regression equations, which are estimated with OLS regressions, involve country $\times$ time clustered standard errors. This is because our key variation of interest (the interaction of the Basel II indicator variable with the indicator variable that traces the countrylevel average credit quality of the counterparty bank) is at the country-time level. We have 25 OECD and 133 non-OECD export-destination countries and

24 Consistent with the Khandelwal, Schott, and Wei 2013) approach, we observe no difference between the treated groups and control groups when we rerun the cross-sectional regressions with double-differenced data (see the even-numbered columns of the Internet Appendix Table A6). 
two periods (after first-differencing the data). In this setting, the number of truly independent clusters of data in each period of our two-period panel is 50 for the OECD and 266 for the non-OECD sample: firm-product pairs in the same country-year will face correlated shocks from common country-specific business cycles (e.g., Bertrand, Duflo, and Mullainathan 2004).

\subsection{Estimates for the sample of OECD countries}

First, we focus on the OECD sample, which is limited to exports to countries that are members of this organization throughout the sample period and whose banks have weighted average ratings that are either investment grade or nonrated given the imposed data restrictions 25

Table 5 presents the findings. The results for Equation (1), our baseline regression, are presented in Column 1 of Table 5. The estimate of the coefficient

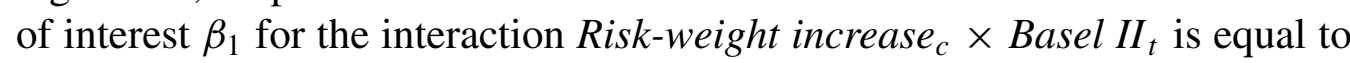
-0.00537 (i.e., -0.537 percentage points), which is statistically significant at the $1 \%$ level. This is an economically significant effect, given that, in Table 2, the pre-Basel II share of letters-of-credit-based exports related with OECD counterparty banks for which the increase in risk weight is equal to 0.0455 (i.e., 4.55 percentage points), on average. Our finding indicates that the share of exports decreases by $-11.80 \%(=-0.00537 / 0.0455)$ as the risk-weight increases with Basel II from 0.20 to 0.50 for countries with banks that are rated A1 to Baa3, on average. This suggests that the riskweight elasticity of letters-of-credit-based share of exports is equal to -0.0787 $(=[-0.00537 / 0.0455] /[(0.50-0.20) / 0.20])$ at the firm-country-product level as the risk weights increase $150 \%$. In other words, for the OECD sample, a $10 \%$ increase in risk weight leads to an approximately $0.8 \%$ decrease in the letters-of-credit-based export shares for firms.

First-difference of the share of letters-of-credit-based exports takes out any confounding effects that are at the firm-country-product level so long as such effects remain constant between annual periods $t=0$ and 1 or between $t=1$ and 2 . Moreover, we saturate the baseline model with country $\times$ product and product $\times$ time fixed effects (all at the HS6 product-code level) that would account for other potential confounding factors (such as country-level demand for a particular Turkish export product, or aggregate demand for a particular product over time). Nevertheless, this approach might not remove general Basel II effects that could affect some or all exporters in $t=2$. Such effects could arise, for example, because higher risk-based capital standards may lead to less lending to all or some borrowers (e.g., small- and medium-sized enterprises): firms typically rely on bank credit for working capital, on which exports heavily

25 This means that we can only conduct tests with the assumption that the letters of credit have a remaining maturity of more than three months, because OECD countries with banks that have, on average, below investment-grade ratings drop out of our sample due to the implemented data constraints. Moreover, the only OECD member country with unrated banks in Bankscope is Iceland. 
Table 5

OECD sample regressions

\begin{tabular}{|c|c|c|c|}
\hline & $\begin{array}{l}\text { Baseline } \\
\text { regression }\end{array}$ & $\begin{array}{l}\text { Additional } \\
\text { firm } \times \text { time } \\
\text { fixed effects }\end{array}$ & $\begin{array}{l}\text { Additional } \\
\text { firm } \times \text { product } \times \text { time } \\
\text { fixed effects }\end{array}$ \\
\hline & 1 & 2 & 3 \\
\hline${\text { Risk-weight } \text { increase }_{c} \times \text { Basel II }_{t}}$ & $\begin{array}{l}-0.00537 * * * \\
(-4.85)\end{array}$ & $\begin{array}{l}-0.00588 * * * \\
(-3.80)\end{array}$ & $\begin{array}{l}-0.00592 * * * \\
(-3.79)\end{array}$ \\
\hline Number of observations & 94,366 & 94,366 & 94,366 \\
\hline Regression $R^{2}$ & 0.147 & 0.343 & 0.359 \\
\hline Fixed effects & $\begin{array}{l}\text { Country } \times \text { product, } \\
\text { product } \times \text { time }\end{array}$ & $\begin{array}{l}\text { Country } \times \text { product, } \\
\text { product } \times \text { time, } \\
\text { firm } \times \text { time }\end{array}$ & $\begin{array}{l}\text { Country } \times \text { product, } \\
\text { firm } \times \text { product } \\
\text { HS } 2 \times \text { time }\end{array}$ \\
\hline Clustered standard errors & Country $\times$ time & Country $\times$ time & Country $\times$ time \\
\hline
\end{tabular}

This table presents the estimates of regression:

$$
\Delta \text { Trade-credit export share }_{f, c, p, t}=\beta_{1} . \text { Risk weight increase }_{c} \times \text { Basel }_{I I_{t}}+\gamma_{c, p}+\gamma_{p, t}+\varepsilon_{f, c, p, t}
$$

in which $\Delta$ is the first-difference operator (i.e., $\Delta x_{t}=x_{t}-x_{t-1}$ ); Trade-credit export share f,c,p.t is the share of letters-of-credit-based exports for firm $f$ exporting product $p$ to export-destination country $c$ in period $t$ with respect to total exports along the same dimension during $t$; subscript $t$, with $t \in\{1,2\}$, denotes annual periods in the two-period panel with first-differenced dependent variable, where $t=1$ covers July 1, 2011 through June 30, 2012, $t=2$ corresponds to July 1, 2012 through June 30, 2013 (i.e., the year that follows Basel II adoption date of July 1, 2012; $t=0$, which is implicit in the first differencing, covers July 1, 2010 through June 30, 2011); Risk-weight increase $e_{C}$ is an indicator variable equal to one if the letter of credit-issuer counterparty-banks in the destination OECD country $c$ have, on average, a long-term credit rating between $\mathrm{A} 1$ to Baa3 according to Moody's (or equivalently rated A+ to BBB- by S\&P or Fitch) or are nonrated, and for which the letter of creditassociated risk weights increase from 0.20 to 0.50 following the adoption of Basel II, or zero otherwise; Basel II is an indicator variable equal to one for $t=2$, and zero otherwise; $\gamma_{c, p}$ denotes country $\times$ product fixed effects, and $\gamma_{p, t}$ denotes product $\times$ time fixed effects; and $\varepsilon$ is the error term of the OLS regression. All product fixed effects are at the six-digit Harmonized System (HS6) level, with the exception of the firm-product $\mathrm{HS}_{2}$-time fixed effects in Column 3, which are at the two-digit Harmonized System level. Robust standard errors are clustered at the country $\times$ time level, and the corresponding $t$-statistics are provided within parentheses below the coefficient estimates. $*^{* *}$, and $* * *$ indicate significance at the $10 \%, 5 \%$, and $1 \%$ level, respectively.

depend because payment cycles are longer in international trade compared to domestic trade Beaumont 2016). Less bank lending after Basel II, when combined with risk-weight changes, might affect the composition of exports depending on their types of trade financing. It also could be that there are more changes to bank-exporter relations in Turkey around Basel II. To account for these and other plausible indirect Basel II effects, we re-estimate Equation (1) after adding time-varying firm fixed effects to our baseline regression: in Column 2 of Table 5 the coefficient estimate for Risk-weight increase $e_{c} \times$ Basel $I I_{t}$ is equal to -0.00588 , which is statistically significant at the $1 \%$ level. This suggests that the letters-of-credit-based export share decreases by $12.92 \%$ $(=-0.00588 / 0.0455)$, with an associated elasticity of share of letters-of-creditbased exports to changes in risk weights equal to $-0.0862(=-0.1295 / 1.50)$. These results, which are very similar to the ones based on the $\beta_{1}$ estimate of Column 1 of the same table, show that the change in the share of exports using letters of credit is a within-firm phenomenon. Importantly, the bank credit channel, which is implicitly controlled for through firm $\times$ time fixed effects, cannot explain out results: Our specification in Column 2 of Table 5 is able 
to identify the international trade channel as any indirect Basel II effects are accounted for by the time-varying firm fixed-effects. We conclude that for the OECD sample, any indirect Basel II effects do not materially influence our results.

Next, we estimate Equation (1) with better controls for time-varying firmproduct confounding factors ( such as time-varying demand for individual firms' products). To do so, we replace the combination of product $\times$ time and firm $\times$ time fixed effects of Column 2 with the firm $\times$ product $\times$ time fixed effects, with the product categories defined at the HS2 level 26 The coefficient estimate for the interaction Risk-weight increase $_{c} \times$ Basel $I_{t}$ is not materially affected by the addition of triple-interaction fixed effects: In Table 5. Column 3, the estimate for $\beta_{1}$ is equal to -0.00592 and statistically significant at the $1 \%$ level, a result similar in magnitude to those of Columns 1 and 2 of the same table. We conclude that, for the OECD sample, the increases in the costs of letters of credit have led to a decrease in the share of letter of credit financed exports.

\subsection{Estimates for the sample of non-OECD countries}

In Table 6, we present estimates of Equation (2). In Column 1, the coefficient estimate for the interaction Risk-weight decrease ${ }_{c} \times$ Basel II $_{t}$ is equal to 0.00439 and statistically significant at the $5 \%$ level. The observed impact of riskweight change is not trivial economically: It amounts to a $5.96 \%$ increase in export share, which, prior to the adoption of Basel II, is equal to $7.36 \%$ for investment-grade plus nonrated non-OECD countries. These results are not materially affected when we account for general Basel II or finer time-varying firm-product demand. In Column 2 of Table 6, the coefficient estimate for

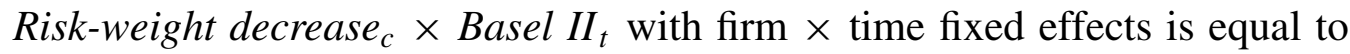
0.00497 and statistically significant at the 5\% level. In Column 3 of Table 6

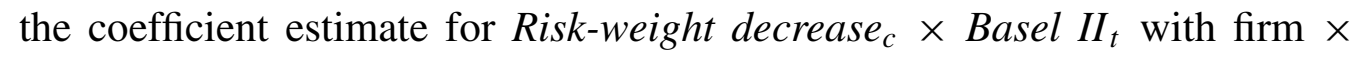
(HS2 level) product $\times$ time fixed effects, is equal to 0.00482 and statistically significant at the $10 \%$ level.

With the non-OECD sample, we also estimate a version of Equation (2) in which Risk-weight decrease is split into two: $80 \%$ Risk-weight decrease $_{c}$ corresponds to the counterparty bank rating range of Aaa to Aa3 (for which the risk weight decreases from 1.00 to 0.20 ) and 50\% Risk-weight decrease c $_{c}$ for counterparty bank ratings between $\mathrm{A} 1$ and Baa3, as well as nonrated cases (for which the risk weight decreases from 1.00 to 0.50). Internet Appendix Table A2 presents the related results. The coefficient estimates for $80 \%$ Riskweight decrease $_{c} \times$ Basel II interactions are never statistically significant,

26 In this specification country $\times$ product fixed effects are still defined at the HS6-level. For firm $\times$ product $\times$ time fixed effects, we limit ourselves to the HS2-level product categories because at the HS6-level the total number of fixed effects (i.e., country $\times$ product and firm $\times$ product $\times$ time all combined together) would have amounted to $63 \%$ of OECD observations and $73 \%$ of the non-OECD observations. 
Table 6

Non-OECD sample regressions

\begin{tabular}{|c|c|c|c|}
\hline & $\begin{array}{l}\text { Baseline } \\
\text { regression }\end{array}$ & $\begin{array}{l}\text { Additional } \\
\text { firm } \times \text { time } \\
\text { fixed effects }\end{array}$ & $\begin{array}{l}\text { Additional } \\
\text { firm } \times \text { product } \times \text { time } \\
\text { fixed effects }\end{array}$ \\
\hline & 1 & 2 & 3 \\
\hline Risk-weight decrease $_{c} \times$ Basel II $_{t}$ & $\begin{array}{l}0.00439 * * \\
(2.49)\end{array}$ & $\begin{array}{l}0.00497 * * \\
(2.04)\end{array}$ & $\begin{array}{l}0.00482 * \\
(1.67)\end{array}$ \\
\hline Number of observations & 126,080 & 126,080 & 126,080 \\
\hline Regression $R^{2}$ & 0.209 & 0.406 & 0.437 \\
\hline Fixed effects & $\begin{array}{l}\text { Country } \times \text { product, } \\
\text { product } \times \text { time }\end{array}$ & $\begin{array}{l}\text { Country } \times \text { product, } \\
\text { product } \times \text { time, } \\
\text { firm } \times \text { time }\end{array}$ & $\begin{array}{c}\text { Country } \times \text { product, } \\
\text { firm } \times \text { product } \mathrm{HS} 2 \times \text { time }\end{array}$ \\
\hline Clustered standard errors & Country $\times$ time & Country $\times$ time & Country $\times$ time \\
\hline
\end{tabular}

This table presents the estimates of regression:

$$
\Delta \text { Trade-credit export share } f_{, c, p, t}=\beta_{1} \text {. Risk-weight decrease }{ }_{c} \times \text { Basel }_{I I_{t}}+\gamma_{c, p}+\gamma_{p, t}+\varepsilon f, c, p, t
$$

in which $\Delta$ is the first-difference operator (i.e., $\Delta x_{t}=x_{t}-x_{t-1}$ ); Trade-credit export share $f, c, p, t$ is the share of letters-of-credit-based exports for firm $f$ exporting product $p$ to export-destination country $c$ in period $t$ with respect to total exports of $f$ in $p$ to $c$ during $t$; subscript $t$, with $\mathrm{t} \in\{1,2\}$, denotes annual periods in the two-period panel with first-differenced dependent variable; $t=1$ covers July 1, 2011 through June 30, 2012; $t=2$ corresponds to July 1, 2012 through June 30, 2013, i.e., the year that follows Basel II adoption date of July 1, $2012(t=0$, which is implicit in the first differencing, covers July 1, 2010 through June 30, 2011); Risk-weight decrease e $_{C}$ is an indicator variable equal to one if the letter of credit-issuing counterparty-banks in the destination non-OECD country $c$ are, on average, rated between Aaa and Baa3 from Moody's (or equivalently rated AAA to BBB- by $\mathrm{S} \& \mathrm{P}$ or Fitch) throughout the sample period and for which group the letter of credit risk-weight decrease from 1.00 to 0.20 with Basel II, or zero otherwise; Basel II $t$ is equal to one for $t=2$, and zero otherwise; $\gamma_{c, p}$ denotes country $\times$ product fixed effects, and $\gamma_{p, t}$ denotes product $\times$ time fixed effects; and $\varepsilon$ is the error term of the OLS regression. All product fixed effects are at the six-digit Harmonized System (HS6) level, with the exception of the triple firm $\times$ product $_{\mathrm{HS} 2} \times$ time fixed effects in Column 3 , which are at the HS2 level. Robust standard errors are clustered at the country $\times$ time level, and the corresponding $t$-statistics are provided within parentheses below coefficient estimates. *, **, and *** indicate significance at the $10 \%, 5 \%$, and $1 \%$ level, respectively.

which might be due to the fact that the corresponding group of countries, whose banks are, on average, rated Aaa through Aa3, include three marginal destination countries for Turkish exports (Hong Kong, Malta, and Singapore) 27 In contrast, in Column 1 of the Internet Appendix Table A2 the coefficient estimate for the interaction $50 \%$ Risk-weight decrease d $_{c} \times$ Basel II is equal to 0.00447 , which is statistically significant at the $5 \%$ level. Similar results are obtained in the other two columns under the different fixed effects combinations.

The non-OECD sample results corroborate those of the OECD sample even though Basel II related shock, a decrease in risk weights, is in the opposite direction: Reductions in the cost of letter of credit financing have led to increases in letter of credit financed export shares. In the next section, we present the estimates of Equation (3) using a pooled OECD and non-OECD sample with a view to improve estimation efficiency.

27 In 2012, Malta received $0.60 \%$ of Turkey's total exports (by value), Singapore 0.29\%, and Hong Kong 0.22\%. 
Table 7

Pooled (OECD plus non-OECD) sample regressions

\begin{tabular}{|c|c|c|c|}
\hline & $\begin{array}{l}\text { Baseline } \\
\text { regression }\end{array}$ & $\begin{array}{l}\text { Additional } \\
\text { firm } \times \text { time } \\
\text { fixed effects }\end{array}$ & $\begin{array}{l}\text { Additional } \\
\text { firm } \times \text { product } \times \text { time } \\
\text { fixed effects }\end{array}$ \\
\hline & 1 & 2 & 3 \\
\hline 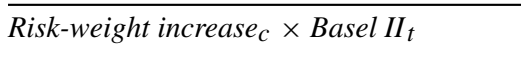 & $\begin{array}{l}-0.00512 * * * \\
(-4.21)\end{array}$ & $\begin{array}{l}-0.00407 * \\
(-1.93)\end{array}$ & $\begin{array}{l}-0.00448 * * * \\
(-2.59)\end{array}$ \\
\hline Risk-weight decrease $_{c} \times$ Basel II $_{t}$ & $\begin{array}{l}0.00457 * * \\
(2.55)\end{array}$ & $\begin{array}{l}0.00551 * * \\
(2.36)\end{array}$ & $\begin{array}{l}0.00539 * * \\
(2.05)\end{array}$ \\
\hline$O E C D_{c} \times$ Basel II $_{t}$ & $\begin{array}{l}0.00771 * * * \\
(4.37)\end{array}$ & $\begin{array}{l}0.0114 * * * \\
(4.24)\end{array}$ & $\begin{array}{l}0.0121 * * * \\
(4.44)\end{array}$ \\
\hline Number of observations & 220,446 & 220,446 & 220,446 \\
\hline Regression $R^{2}$ & 0.176 & 0.334 & 0.364 \\
\hline Fixed effects & $\begin{array}{l}\text { Country } \times \text { product, } \\
\text { product } \times \text { time }\end{array}$ & $\begin{array}{l}\text { Country } \times \text { product, } \\
\text { product } \times \text { time, } \\
\text { firm } \times \text { time }\end{array}$ & $\begin{array}{c}\text { Country } \times \text { product, } \\
\text { firm } \times \text { product }_{\mathrm{HS} 2} \times \text { time }\end{array}$ \\
\hline Clustered standard errors & Country $\times$ time & Country $\times$ time & Country $\times$ time \\
\hline $\begin{array}{l}H_{0}: \text { Risk-weight increase } e_{c} \times \text { Basel II }_{t}= \\
\text { Risk-weight decrease }_{c} \times \text { Basel II }_{t}\end{array}$ & $18.89 * * *$ & $10.34 * * *$ & $10.92 * * *$ \\
\hline $\begin{array}{l}H_{0}: \mid \text { Risk-weight increase }_{c} \times \text { Basel II }_{t} \mid= \\
\mid \text { Risk-weight decrease }_{c} \times \text { Basel II }_{t} \mid\end{array}$ & 0.0678 & 0.189 & 0.0761 \\
\hline
\end{tabular}

This table presents the estimates of regression equation:

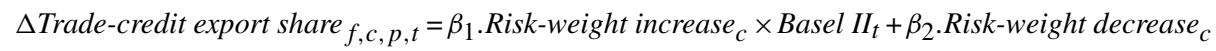

$$
\begin{aligned}
& \times \text { Basel } I_{t}+\beta_{3} . \text { OECD } \times \text { Basel } \mathrm{II}_{t}+\gamma_{c, p}+\gamma_{p, t}+\varepsilon_{f, c, p, t}
\end{aligned}
$$

in which $\Delta$ is the first-difference operator (i.e., $\Delta x_{t}=x_{t}-x_{t-1}$ ); Trade-credit export share $f, c, p, t$ is the share of letters-of-credit-based exports for firm $f$ exporting product $p$ to export-destination country $c$ in period $t$ with respect to total exports of $f$ in $p$ to $c$ during $t$; subscript $t$ denotes annual periods in the two-period panel of firstdifferenced dependent variable with $t \in\{1,2\}$ ( $t=1$ covers July 1, 2011 through June 30, 2012; $t=2$ corresponds to July 1, 2012 through June 30, 2013; $t=0$, which is implicit in the first-differencing, covers July 1, 2010 through June 30, 2011); Risk-weight increase $_{C}$ (Risk-weight decrease C $_{\text {) }}$ is equal to one if the risk weights for letters of credit increase (decrease) following the adoption of Basel II (increases correspond to OECD countries and decreases to non-OECD countries); $O E C D_{c}$ is equal to one if country $c$ is an OECD-member throughout the sample period; $\gamma_{c, p}$ denotes country $\times$ product fixed effects, and $\gamma_{p, t}$ denotes product $\times$ time fixed effects; and $\varepsilon$ is the error term of the OLS regression. All product fixed effects are at the six-digit Harmonized System (HS6) level, with the exception of the triple firm $\times$ product $_{\mathrm{HS} 2} \times$ time fixed effects in Column 3 , which are at the HS2 level. Robust standard errors are clustered at the country $\times$ time level, and the corresponding $t$-statistics are provided within parentheses below coefficient estimates. *,**, and *** indicate significance at the $10 \%, 5 \%$, and $1 \%$ level, respectively.

\subsection{Estimates for the pooled (OECD plus non-OECD) sample}

We estimate Equation (3) under the assumption that the letters of credit have longer than three months of maturity, on average ${ }^{28}$ In Column 1 of Table7 the coefficient estimate for Risk-weight increase $e_{c} \times$ Basel $I_{t}$, which corresponds to the A1-Baa3 and nonrated counterparties located in OECD countries (as traced by our country-level proxy) subjected to an increase in risk weights (from 0.20 to 0.50 ), is equal to -0.00512 , which is statistically significant at

28 Estimating Equation (3) under the assumption that the letters of credit have shorter than three months of

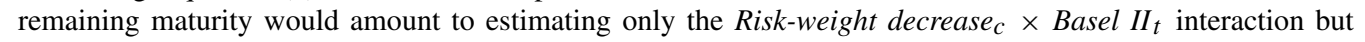

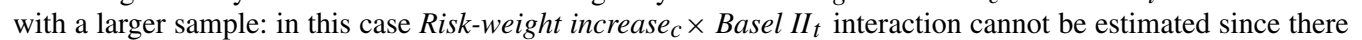
is no corresponding change in the risk weights in this case (given that we have no OECD country in our sample with banks that are rated below investment grade, on average; see also Table 1. 
the $1 \%$ level. This estimate is similar to the coefficient estimate of -0.00537 in Column 1 of Table 5. In Column 1 of Table 7 the coefficient estimate for Risk-weight decrease ${ }_{c} \times$ Basel II $_{t}$, which corresponds to the investment-grade and nonrated non-OECD-based counterparty banks for which the risk weights decrease, is equal 0.00457 and statistically significant at the 5\% level. Again, this estimate is similar to the estimate of 0.00447 for the Risk-weight decrease ${ }_{c}$ $\times$ Basel $\mathrm{II}_{t}$ interaction in Column 1 of Table 6

The pooled sample regression gives us the possibility to test for the equality the coefficient estimates of Risk-weight increase ${ }_{c} \times$ Basel II $_{t}$ and Risk-weight decrease $_{c} \times$ Basel II $_{t}$. These tests are provided at the bottom of Column 1 in Table 7 We reject the null hypothesis that the coefficient estimate of -0.00512 for Risk-weight increase $_{c} \times$ Basel $I_{t}$ equals the coefficient estimate of 0.00457

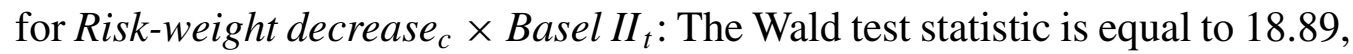
which statistically significant at the $1 \%$ level. In a second step, we test whether the observed effect is symmetric. That is, we test for the equality of the absolute values of the observed coefficient estimates: the test statistic is equal to 0.0678 , which is not statistically significant. So the effect Basel II adoption on letter of credit based exports appears to be of similar magnitudes even if it is of different directions for the risk-weight increases versus decreases.

We have similar estimates for the interactions of interest in Column 2 (with the addition of firm $\times$ time fixed effects to Equation (3)) and Column 3 (with the addition of and firm $\times(\mathrm{HS} 2$ level) product $\times$ time fixed effects) of Table 7 Overall, the pooled sample estimates are line with our estimates using separate OECD and non-OECD samples.

However, these findings do not clarify the actual impact, if any, of Basel II related risk-weight changes on total trade at the firm-product-country level. We examine this question next.

\subsection{Trade growth regressions}

In Table 8 we present the estimates of trade growth regressions for the OECD and non-OECD samples, respectively, in which we test whether Basel II actually affected total trade (aggregated over all payment terms) at the firm-countryproduct level. In Column 1 of Table 8, we present the estimates of Equation (4) for the OECD total trade growth. In this case, we are interested in the

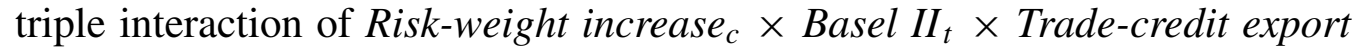
share $_{f, c, p, t=0}$ for which the coefficient estimate is equal to -0.0557 but is not statistically significant. Despite having the correct negative sign, our test indicates that, for higher letter of credit export share in the pre-Basel II period, the risk-weight increases brought about by Basel II did not affect total firmcountry-product level exports to destinations whose banks are, on average, A1-Baa3 rated.

In Table 8, Column 2, we find similar results for the non-OECD sample. Here our test relies on the triple interaction of Risk-weight decrease ${ }_{c} \times$ Basel $I I_{t} \times$ Trade-credit export share $_{f, c, p, t=0}$, for which the coefficient estimates are 
Table 8

Firm-destination-product-level trade growth regressions

\begin{tabular}{|c|c|c|}
\hline & OECD sample & Non-OECD sample \\
\hline & 1 & 2 \\
\hline $\begin{array}{l}\text { Risk-weight } \text { increase }_{c} \times \text { Basel } I_{t} \times \text { Trade-credit export } \\
\text { share } f, c, p, t=0\end{array}$ & $\begin{array}{l}-0.0557 \\
(-0.30)\end{array}$ & \\
\hline $\begin{array}{l}\text { Risk-weight decrease } \\
\quad \text { share }_{f, c, p, t=0} \times \text { Basel } \mathrm{II}_{t} \times \text { Trade-credit export }\end{array}$ & & $\begin{array}{l}0.0749 \\
(0.44)\end{array}$ \\
\hline Risk-weight increase $_{c} \times$ Trade-credit export share $_{f, c, p, t=0}$ & $\begin{array}{l}0.00471 \\
(0.03)\end{array}$ & \\
\hline Risk-weight decrease $_{c} \times$ Trade-credit export share $_{f, c, p, t=0}$ & & $\begin{array}{l}-0.0212 \\
(-0.15)\end{array}$ \\
\hline Basel II $I_{t} \times$ Trade-credit export share $f_{f, c, p, t=0}$ & $\begin{array}{l}0.383^{* *} \\
(2.57)\end{array}$ & $\begin{array}{l}0.233^{*} \\
(1.94)\end{array}$ \\
\hline Trade-credit export share $f, c, p, t=0$ & $\begin{array}{l}-0.350^{* * *} \\
(-3.02)\end{array}$ & $\begin{array}{l}-0.295^{* * *} \\
(-2.98)\end{array}$ \\
\hline Number of observations & 94,366 & 126,080 \\
\hline Regression $\mathrm{R}^{2}$ & 0.315 & 0.436 \\
\hline Fixed effects & Country $\times$ product $\times$ time & Country $\times$ product $\times$ time \\
\hline Clustered standard errors & Country $\times$ time & Country $\times$ time \\
\hline
\end{tabular}

Column 1 (Column 2) presents the estimates of regression equation for the OECD (non-OECD) sample (where

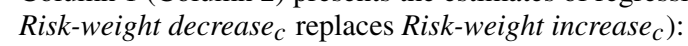

$$
\begin{aligned}
& \Delta \ln \left(\text { Total exports }_{f, c, p, t}\right)=\beta_{1} \text {. Risk-weight } \text { increase }_{c} \times \text { Basel } I_{t} \times \text { Trade-credit export share }_{f, c, p, t=0}
\end{aligned}
$$

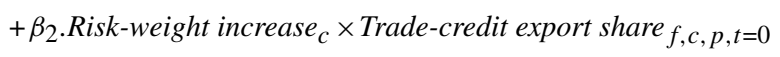

$$
\begin{aligned}
& +\beta_{3} \text {.Basel } I_{t} \times \text { Trade-credit export share } f, c, p, t=0 \\
& +\beta_{4} \text {.Trade-credit export share } f_{f, c, p, t=0}+\gamma_{c, p, t}+\varepsilon_{f, c, p, t}
\end{aligned}
$$

in which $\Delta$ is the first-difference operator (i.e., $\Delta x_{t}=x_{t}-x_{t-1}$ ) with $\mathrm{t} \in\{1,2\}$, denotes annual periods in the two-period panel ( $t=1$ covers July 1, 2011 through June 30, 2012; $t=2$ corresponds to July 1, 2012 through June 30,2013 ); $\ln$ (Total exports $f, c, p, t$ ) is the natural logarithm of the value of total exports (with all types of export financing combined) of firm $f$ to country $c$ for a given product $p$ in period $\mathrm{t}$; Risk-weight increase $_{c}$ is an indicator variable equal to one if the letter of credit-issuer counterparty-banks in the destination OECD country $c$ have, on average, a long-term credit rating between A1 to Baa3 according to Moody's (or equivalently rated A+ to BBBby S\&P or Fitch) or are non-rated, and for which the letter of credit-associated risk weights increase from 0.20 to 0.50 following the adoption of Basel II, or zero otherwise; Risk-weight decrease $e_{c}$ is an indicator variable equal to one if the letter of credit-issuing counterparty-banks in the destination non-OECD country $c$ are, on average, rated between Aaa and Baa3 from Moody's (or equivalently rated AAA to BBB- by S\&P or Fitch) throughout the sample period and for which group the letter of credit risk-weight decrease from 1.00 to 0.20 with Basel II, or zero otherwise; Basel $I I_{t}$ is equal to one for $t=2$ post Basel II, and zero otherwise; Trade-credit export share $_{f, c, p, t=0}$ is the share of letters-of-credit-based exports for firm $f$ exporting product $p$ to export-destination country $c$ in period $t=0$ (which covers July 1, 2010 through June 30,2011) with respect to total exports of $f$ in $p$ to $c$ during the same period; $\gamma_{c, p, t}$ denotes country $\times$ product $\times$ time fixed effects; and $\varepsilon$ is the error term of the OLS regression. Robust standard errors are clustered at the country $\times$ time level, and the corresponding $t$-statistics are provided within parentheses below coefficient estimates. $*$, **, and $* * *$ indicate significance at the $10 \%, 5 \%$, and $1 \%$ level, respectively.

0.0749 , which is not statistically significant. While the coefficient estimate of interest has the anticipated positive sign (i.e., the drop in the risk weights is associated with positive total trade growth for flows with high letters-of-creditbased export shares in the pre-Basel II), it is not statistically significant.

\subsection{Discussion}

The failure to find a statistically significant result for the total export growth using neither the OECD nor the non-OECD sample suggests that Basel II 
did not affect trade at the firm-product-country level when all payment types are combined. This is despite the fact that the share of letters-of-credit-based exports is affected as suggested by the trade credit channel of exports. The lack of statistically significant results for the growth regressions suggests that trade finance channel is not important for exports. Instead, the growth regression findings are consistent with accommodation through payment terms following adoption of Basel II. That is, as risk weights changed with Basel II, Turkish exporters appear to have accommodated the resultant changes in the costs of letter of credit by switching to other payment terms for international finance. One could view such behavior as a form of regulatory arbitrage 29

There are several possible explanations for the lack of support for the trade finance channel. First, at the time of our quasi-natural experiment, the Turkish banks were well capitalized: Adopting Basel II has led to a $1.5 \%$ decrease in their risk-based capital ratios, leaving the banking sector capitalized at roughly $15 \%$. This is important, because the trade finance channel may become more significant during crises when firms are less likely to have access to trade credit extended by their trade partners or they face increased nonpayment risk for their export sales. For example, Antras and Foley 2015) and Paravisini et al. (2015) find little substitution between the methods of payment at the time of the Great Recession of 2008-2009. Second, it could be that the bank credit channel, which our firm $\times$ time fixed effects implicitly control for, might be more important than the trade finance channel. A shock to the availability of short-term bank credit could affect export performance because it could lead to working capital shortages. Payment terms are longer in international finance. As a result, the role of working capital becomes even more important than the role it plays in domestic trade Beaumont 2016.

Our contribution in this paper is to make use of Basel II's adoption in Turkey to clearly identify the trade-finance channel while controlling for the more general bank credit channel. Earlier papers could not or did not differentiate between the trade finance channel and the bank credit channel (e.g.. Amiti and Weinstein 2011; Chor and Manova 2012). Other papers have focused on the bank credit channel. For example, in Paravisini et al. 2015), who do not observe trade finance instruments directly but make use of exogenous shocks to the general level of company-level bank funding, the bulk of the bank-shock lending effect points to the working capital channel at play. In their case, export sensitivity does not depend on variables measuring typically export-specific finance needs. Moreover, the contribution of noncredit factors to the fall in Peruvian exports during the Great Recession was larger than that of creditrelated factors. As another example, Del Prete and Federico (2014), who use detailed Italian data on bank-firm loan types, observe an effect of bank shocks

29 For examples of regulatory arbitrage by banks, see for example, Boyson, Fahlenbrach, and Stul7 2016), Demyanyk and Loutskina 2016), and Yorulmaze 2012). 
on general level of firm exports. Yet they find that only the provision of general loans, but not trade-related lending, matters 30

Our findings are also in line with those of Levchenko, Lewis, and Tesan 2010) and Eaton et al. 2016), who note that the bulk of the decrease in international trade during the Great Recession could be attributed to a fall in durable goods' trade (probably linked with a fall in demand for such goods) rather than a pure finance-channel effect. The observed comovement in the demand and trade financing in various empirical studies of global exports in durable goods industries, such as metals, machinery, or transportation, may be due to the fact that these are also more trade-finance intensive (e.g., see Table 3).

Our results also have important policy implications. Many institutions involved in global trade raise serious concerns regarding the treatment of financial instruments related with international trade under later versions of risk-based capital requirements proposed by the Basel Committee on Bank Regulation. For example, in 2009 Robert Zoellick, the then-president of the World Bank, suggested that $10 \%-15 \%$ of the decrease in global trade during the Great Recession might be due to lower provision of trade finance under Basel II Financial Times 2009) 313 A 2009 survey by the International Chamber of Commerce (ICC) reports that "the feedback ... on Basel II ... [suggests] that most banks are facing tougher capital requirements for their [international] trade assets" (ICC 2009, 40). Other banking surveys indicate that (1) Basel II had a negative impact on banks' provision of trade finance for most large international financial institutions and that (2) for a nonnegligible proportion of banks the increase in the cost of trade finance products is linked with higher capital requirements Asmundson et al.2011). Our findings suggest that these worries appear to be overstated. While Basel II related changes in the treatment of letters of credit have an impact on the export shares financed with these instruments, we cannot find any impact on total trade growth. Parties involved in international trade appear to be able to accommodate the changes to the costs of letters of credit financing.

\section{Robustness Checks}

As a first check, we redefine Trade-credit export share with respect to the average of total exports over two consecutive periods and estimate the socalled "midpoint regressions" (e.g., Davis and Haltiwangen 1992, 1998) to rule

30 Some other studies that do not use direct bank- or firm- data point in the same direction. For example, Behrens, Corcos, and Mion 2013) find that while exports of Belgian firms with shorter maturity of debt or a larger fraction of financial debt shrank more during the Great Recession, their exports-to-turnover ratio (that is, including domestic sales) did not, going against the trade-finance channel story.

31 Similar fears have been raised for Basel III, which initially proposed that a $100 \%$ capital earmark be set aside for many off-balance sheet items, including letters of credit (see, for example, Masters 2010; Evans 2011). Upon consultations with the World Bank, the World Trade Organization (WTO), and the ICC, the BIS relaxed certain aspects of capital requirements for international trade instruments under Basel II and III Masters 2011; BIS, October 2011). 
out the influence of zero trade shares. The results in the first columns of the Internet Appendix Tables A3 through A5, confirm our main findings 32

Second, we test whether our results could be due to unaccounted demand factors. To do so, we add $\Delta$ Imports $_{c, t}$ (the global imports, from the IMF DOTS database, excluding Turkish exports, of country $c$ in annual period $t$ ) and $\Delta$ Sovereign rating $g_{c, t}$ (the change in sovereign rating for country $c$ during period $t$ ) to our specification. Results in the second columns of the Internet Appendix Tables A3 through A5 suggest that adding these two variables does not affect our results. In Column 3 of the same tables, our coefficient estimates of interest remain unaffected with country-specific time trends.

Third, to rule out that our results could be driven by possible shifts across credit conversion factors, we limit our sample to the particular case of metals. This group of products is composed of standardized manufactured goods (such as sheet or rod iron and steel) that can be easily collateralized, in which case the credit-conversion factor is equal to $20 \%$. In Column 4 of the Internet Appendix Tables A3-A5, our results remain the same when the credit conversion factor is highly likely to stay constant at $20 \%$.

Fourth, we conduct a placebo test by using the fictitious Basel II adoption date of July 1, 2011, using the July 2009-June 2012 sample. In the last columns of the Internet Appendix Tables A3-A5, we find no statistically significant effects that could be due to banks' anticipation of Basel II 33

Fifth, we provide formal statistical tests of differences in trends in the levels of the Trade-credit export share. In cross-sectional regressions, the coefficient estimates for Basel II interactions are statistically significant: There are nonparallel trends in the pre-Basel II data between the treated and control groups (see the odd-numbered columns of the Internet Appendix Table A6). However, Basel II interactions are not statistically significant when we run the same regressions with double-differenced pre-Basel II data (see the evennumbered columns of the Internet Appendix Table A6), justifying our use of Khandelwal, Schott, and Wei (2013) approach.

Sixth, we check whether the statistical significance of our results depends on the clustering of the standard errors along the country-time dimension: $t$-statistics based on five different clustering options presented in the Internet Appendix Table A7 indicate that this is not the case.

Seventh, and finally, we examine the dispersion of counterparty bank ratings. Figure 3 and the Internet Appendix Table A8 suggest that counterparty bank ratings show very little variation: Our results are unlikely to be driven by shifts or heterogeneity in bank ratings.

32 In fact, in the midpoint regression of the Internet Appendix Table A5, Column 1, under the assumption that the letter of credits' remaining maturities are longer than three months, we observe a statistically significant coefficient estimate for $80 \%$ Risk-weight decrease $\times$ Basel II (as opposed to the comparable estimates of the Internet Appendix Table A2, which are not statistically significant).

33 The placebo tests also suggest that the triple-difference regressions remove the differences in pre-Basel II time trends between the treatment and control groups that we observe in the nondifferenced dependent variable. 

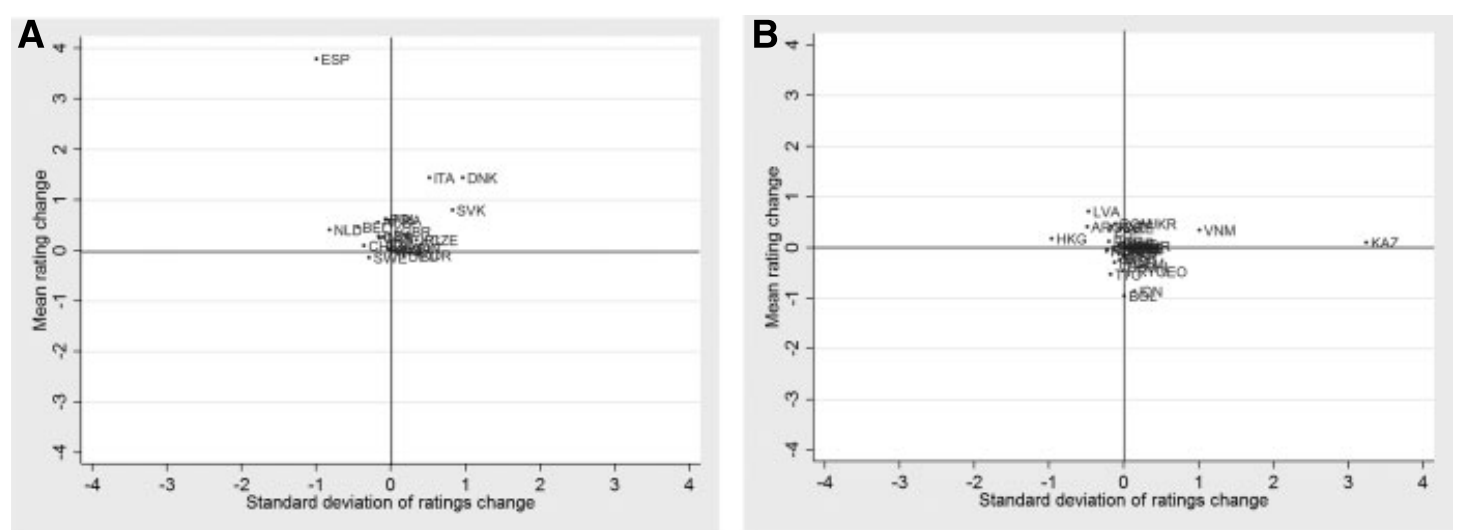

Figure 3

Changes in the means and standard deviations of OECD and non-OECD bank ratings

Figure 3A plots the changes in the (total assets weighted) mean of individual bank ratings per OECD country (y-axis) against the changes in the associated standard deviation ( $x$-axis). Figure $3 \mathrm{~B}$ plots the same variables for the non-OECD member countries. Agency bank ratings, which are from Bankscope database, have been assigned numerical values as follows: one to the rating of Aaa by Moody's or AAA by S\&P and Fitch, two to Aa1 or $\mathrm{AA}+$, three to $\mathrm{Aa} 2$ or AA, etc. The country-level bank-total asset-weighted means and standard deviations are calculated over two annual periods $t=1$ (July 1, 2011 through June 30, 2012) and $t=2$ (July 1, 2012 through June $30,2013)$. Changes are calculated between these two annual periods for each country.

\section{Conclusion}

In this paper, we provide the first direct test of the trade-finance channel of international trade (i.e., exports) that works through letters of credit, while we control for the more general bank lending channel. Our findings indicate that changes in risk-based capital standards that affect costs of holding letters of credit impact export patterns at the firm-country-product level.

In the Turkish case that we study, all banks had to apply risk weights as a function of the agency rating of the counterparty bank after the uniform adoption of the standardized approach of Basel II in mid-2012. These changes generate two sets of identification schemes in which the shocks move in opposite directions for the Turkish exports to the OECD- and non-OECD-member countries. We estimate difference-in-differences regressions that implicitly take into account firm-country-product-level confounding factors.

We find that even though the letters-of-credit-based export shares are affected by Basel II's adoption in Turkey, the total exports are not. This suggests that the effect of higher risk-based capital requirements on exports is subtler than the one anticipated in the popular press and by international trade organizations 34 In fact, our results indicate that, in the particular case of letters of credit financed exports, the shocks to the trade-finance channel appear to play a less important role in determining the export flows. This points to the relevance of the more

34 In a similar vein, Fraisse, Lé, and Thesman 2015) find that the 2008 adoption of Basel II in France had subtler effects than expected. Under Basel II aggregate firm borrowing and investment increased in France, allowing the preservation of jobs during a crisis period as average bank capital required for industrial loans decreased by $2 \%$, on average. 


\section{general bank credit channel that was picked up inter alia by Paravisini et al. 2015) or Del Prete and Federico (2014).}

\section{References}

Ahn, J. 2014. Understanding trade finance: Theory and evidence from transaction-level data. Working Paper, International Monetary Fund.

Amiti, M., and D. Weinstein. 2011. Exports and financial shocks. Quarterly Journal of Economics 126:1841-77.

Antras, P., and C. F. Foley. 2015. Poultry in motion: a study of international trade finance practices. Journal of Political Economy 123:809-852.

Asmundson, I., T. Dorsey, A. Khachatryan, I. Niculcea, and M. Saito. 2011. Trade and trade finance in the 2008-09 Financial Crisis. Working Paper, International Monetary Fund.

BDDK Directive. 2006. Bankacılık Duz̈enleme ve Denetleme Kurumu. Bankaların sermaye yeterliliğinin ölçülmesine ve değerlendirilmesine ilişkin yönetmelik, 1 Kasım 2006 tarih ve 26333 sayılı Resmi Gazete'de yayımlanmıştır (Banking Regulation and Examination Board Directive Regarding the Measurement and Evaluation of Banks' Capital Requirements, published in the Official Journal number 26333 dated November 1).

—. 2012. Bankacilık Duz̈enleme ve Denetleme Kurumu. Yönetmelik, 28 Haziran 2012 tarih ve 28332 sayılı Resmi Gazete'de yayımlanmıştır (Banking Regulation and Examination Board. Directive (published in the Official Journal number 28337 dated June 28)).

BDDK Report. 2007. Basel II ikinci sayısal etki çalışması (QIS-TR2) Değerlendirme raporu (Basel II second quantitative impact study (QIS-TR2) Evaluation report, July).

Behrens, K., G. Corcos, and G. Mion. 2013. Trade crisis? What trade crisis? Review of Economics and Statistics 95:702-9.

Bertrand, M., E. Duflo, and S. Mullainathan. 2004. How much should we trust differences-in-differences estimates? Quarterly Journal of Economics 119:249-75.

Beaumont, P. 2016. Time Is Money: Cash-flow risk and product market behavior. Working Paper, Ecole Polytechnique.

BIS. 2011. Treatment of trade finance under the Basel capital framework, October. Bank for International Settlements, Basel Committee on Banking Supervision.

Boyson, N. M., R. Fahlenbrach, and R. M. Stulz. 2016. Why do banks practice regulatory arbitrage? Evidence from usage of trust preferred securities. Review of Financial Studies 29:1821-59.

Chor, D., and K. Manova. 2012. Off the cliff and back? Credit conditions and international trade during the global financial crisis. Journal of International Economics 87:117-33.

Davis S. J., and J. C. Haltiwanger. 1992. Gross job creation, gross job destruction, and employment reallocation. Quarterly Journal of Economics 107:819-63.

Davis S. J., J. C. Haltiwanger, and S. Schuh. 1998. Job creation and destruction. Cambridge, MA: MIT Press.

Del Prete, S., and S. Federico. 2014. Trade and finance: Is there more than just 'trade finance'? Evidence from matched bank-firm data. Working Paper, Bank of Italy.

Demir, B., and B. Javorcik. 2014. Grin and bear it: Producer-financed exports from an emerging market. Discussion Paper, CEPR.

Demyanyk, Y., and E. Loutskina. 2016. Mortgage companies and regulatory arbitrage. Journal of Financial Economics 122:328-51.

Dombey, D. 2013. Iran, Turkey, and the gold-for-gas trade. Financial Times, February 28.

Dombey, D. and F. Guler. 2013. Economic pressures tarnish Turkey’s gold trade. Financial Times, March 24. 
Eaton, J., S. Kortum, B. Neiman, and J. Romalis. 2016. Trade and the global recession. American Economic Review 106:3401-38.

Evans, J. 2011. Regulate and be damned. Wall Street Journal, February 6.

Financial Times. 2009. Zoellick urges global response. Financial Times, February 19.

2013. Banks suspected of tweaking risk measure. Financial Times, February 26.

Fraisse, H., M. Lé, and D. Thesmar. 2015. The real effects of bank capital requirements. Working Paper, SSRN.

Hoefele, A., T. Schmidt-Eisenlohr, and Z. Yu. 2016. Payment choice in international trade: Theory and evidence from cross-country firm level data. Canadian Journal of Economics 49:296-319.

ICC. 2009. Rethinking trade finance 2009: An ICC global survey. Banking Commission Market Intelligence Report. Paris, France: International Chamber of Commerce.

2011. Global risks - trade finance 2011. Paris, France: International Chamber of Commerce.

Khandelwal, A. K., P. K. Schott, and S.-J. Wei. 2013. Trade liberalization and embedded institutional reform: Evidence from Chinese exporters. American Economic Review 103:2169-95.

Lee, M. J. 2016. Generalized difference in differences with panel data and least squares estimator. Sociological Methods and Research 45:134-57.

Levchenko, A., L. Lewis, and L. Tesar. 2010. The collapse in international trade during the 2008-2009 Financial Crisis: in search of the smoking gun. IMF Economic Review 58:214-53.

Manova, K., and Z. Zhang. 2012. Export prices across firms and destinations. Quarterly Journal of Economics 127:379-436

Masters, B. 2010. Impact of Basel II: Trade finance may become a casualty. Financial Times, October 19.

- 2011. Basel to change trade finance reforms. Financial Times, October 25.

Mora, R. and I. Reggio. 2013. Treatment effect identification using alternative parallel assumptions. Working Paper, Universidad Carlos III de Madrid.

Niepmann, F., and T. Schmidt-Eisenlohr. 2017. International trade, risk and the role of banks. Journal of International Economics 107:111-126.

Paravisini, D., V. Rappoport, P. Schnabl, and D. Wolfenzon. 2015. Dissecting the effect of credit supply on trade: Evidence from matched credit-export data. Review of Economic Studies 85:333-59.

Schmidt-Eisenlohr, T. 2013. Towards a theory of trade finance. Journal of International Economics 1:96-112.

Yorulmazer, T. 2012. Has financial innovation made the world riskier? CDS, regulatory arbitrage and systemic risk. Working Paper, Federal Reserve Bank of New York. 